University of Nebraska - Lincoln

DigitalCommons@University of Nebraska - Lincoln

Papers in the Earth and Atmospheric Sciences

Earth and Atmospheric Sciences, Department

4-2011

\title{
Late Pleistocene paleohydrography and diatom paleoecology of the central basin of Lake Malawi, Africa
}

\author{
Jeffery R. Stone \\ University of Nebraska-Lincoln, jeffery.stone@indstate.edu \\ Karlyn S. Westover \\ University of Nebraska-Lincoln \\ Andrew S. Cohen \\ University of Arizona, cohen@email.arizona.edu
}

Follow this and additional works at: https://digitalcommons.unl.edu/geosciencefacpub

Part of the Earth Sciences Commons

Stone, Jeffery R.; Westover, Karlyn S.; and Cohen, Andrew S., "Late Pleistocene paleohydrography and diatom paleoecology of the central basin of Lake Malawi, Africa" (2011). Papers in the Earth and Atmospheric Sciences. 279.

https://digitalcommons.unl.edu/geosciencefacpub/279

This Article is brought to you for free and open access by the Earth and Atmospheric Sciences, Department of at DigitalCommons@University of Nebraska - Lincoln. It has been accepted for inclusion in Papers in the Earth and Atmospheric Sciences by an authorized administrator of DigitalCommons@University of Nebraska - Lincoln. 
Published in Palaeogeography, Palaeoclimatology, Palaeoecology 303:1-4 (April 1, 2011), pp. 51-70; doi: 10.1016/j.palaeo.2010.01.012

Special isssue: Southern hemisphere tropical climate over the past 145ka: Results of the Lake Malawi Scientific Drilling Project, East Africa. Copyright (c) 2010 Elsevier B.V. Used by permission.

Submitted March 31, 2008; revised September 3, 2009; accepted January 7, 2010; published online January 13, 2010.

\title{
Late Pleistocene paleohydrography and diatom paleoecology of the central basin of Lake Malawi, Africa
}

\author{
Jeffery R. Stone, ${ }^{1,3}$ Karlyn S. Westover, ${ }^{1,2}$ and Andrew S. Cohen ${ }^{3}$ \\ 1. Department of Geosciences, University of Nebraska-Lincoln, 214 Bessey Hall, Lincoln, NE, 68588 USA \\ 2. Department of Ecology and Environmental Science, Umeå University, Umeå, 90187 Sweden \\ 3. Department of Geosciences, University of Arizona, Gould-Simpson Building \#77, 1040 E 4th St., Tucson, AZ, 85721 USA \\ Corresponding author - J. R. Stone, Department of Geosciences, University of Nebraska-Lincoln, \\ 214 Bessey Hall, Lincoln, NE, 68588 USA.; email jstone@unlserve.unl.edu
}

\begin{abstract}
Analysis of sedimentary diatom assemblages (10 to $144 \mathrm{ka})$ form the basis for a detailed reconstruction of the paleohydrography and diatom paleoecology of Lake Malawi. Lake-level fluctuations on the order of hundreds of meters were inferred from dramatic changes in the fossil and sedimentary archives. Many of the fossil diatom assemblages we observed have no analog in modern Lake Malawi. Cyclotelloid diatom species are a major component of fossil assemblages prior to $35 \mathrm{ka}$, but are not found in significant abundances in the modern diatom communities in Lake Malawi. Salinity- and alkalinity-tolerant plankton has not been reported in the modern lake system, but frequently dominant fossil diatom assemblages prior to $85 \mathrm{ka}$. Large stephanodiscoid species that often dominate the plankton today are rarely present in the fossil record prior to $31 \mathrm{ka}$. Similarly, prior to $31 \mathrm{ka}$, common central-basin aulacoseiroid species are replaced by species found in the shallow, well-mixed southern basin. Surprisingly, tychoplankton and periphyton were not common throughout prolonged lowstands, but tended to increase in relative abundance during periods of inferred deeper-lake environments.

A high-resolution lake level reconstruction was generated by a principle component analysis of fossil diatom and wetsieved fossil and mineralogical residue records. Prior to $70 \mathrm{ka}$, fossil assemblages suggest that the central basin was periodically a much shallower, more saline and/or alkaline, well-mixed environment. The most significant reconstructed lowstands are $\sim 600 \mathrm{~m}$ below the modern lake level and span thousands of years. These conditions contrast starkly with the deep, dilute, dysaerobic environments of the modern central basin. After $70 \mathrm{ka}$, our reconstruction indicates sustained deeper-water environments were common, marked by a few brief, but significant, lowstands. High amplitude lake-level fluctuations appear related to changes in insolation. Seismic reflection data and additional sediment cores recovered from the northern basin of Lake Malawi provide evidence that supports our reconstruction.
\end{abstract}

Keywords: diatoms, Pleistocene, lake levels, East Africa, paleoclimate

\section{Introduction}

Although rare in continental settings, sediment archives spanning more than 100,000 years provide valuable information about long-term climate history. Very deep lakes, which can persist through severe and prolonged periods of aridity (Cohen, 2003), often accumulate sediment continuously over exceptionally long periods. In regions where precipitation and evapotranspiration are nearly equal, climate shifts can produce dramatic fluctuations in lake level, records of which may be preserved in the sediment.

Consequently, the Great Lakes of tropical East Africa, with their vast depths, anoxic bottom waters, high primary productivity, and delicate hydrologic budgets, are ideal candidates for long-term paleoclimatic studies (Nicholson, 1998).

Large-scale fluctuations in lake level often result in substantial changes to lake hydrography, hydrology, nutrient cycling, and biological habitat availability; diatoms are highly sensitive to these types of changes in the water environment, and as such frequently are used to infer paleoclimate change from lake sediments (Fritz, 1996). Although the dominant flora may vary inter-annually, sampling of sediment archives typically averages multiple years. As a result, fossil diatom assemblages that have been extracted from sediments in deep-water regions of large lakes indicate long-term average environmental conditions; often these records are marked by long periods (e.g., millennial in scale) with little change to the fossil assemblage (Kilham, 1990).

Here we present a reconstruction of the Late Pleistocene $(10,000$ to 144,000 years BP) diatom paleoecology of the central basin of Lake Malawi. Many of the diatom taxa we observed are endemic to Lake Malawi or commonly confined to deep East African lakes. In many cases the fossil assemblages have no modern analog in Lake Malawi; hence, our paleoecological inferences rely on ecological information drawn from the modern 
distribution of individual taxa in Lake Malawi and other indicators of ancient depth and lake setting. These include the concentration, composition, and taphonomy of the fossil remains of ostracodes (discussed more fully in Park and Cohen, 2011) and chaoborids, sedimentology and structure of the core, and unambiguous geophysical markers of past shorelines. The fossil diatom data is also used to refine the Cohen et al. (2007) reconstruction of late Pleistocene lake-level change, which was based on biological and sedimentological indicators but did not include diatoms.

\subsection{Climatic and hydrographic setting}

Lake Malawi is the southernmost of the Great Lakes of East Africa (9-14 ${ }^{\circ}$, Figure 1$)$; it is one of the largest and deepest lakes in the world, containing approximately 7\% of the Earth's total fresh surface water (Patterson and Kachinjika, 1995). The lake and surrounding catchment are highly sensitive to hydrological variations and experience a strongly seasonal climate (Owen et al., 1990). The austral summer (Dec-Apr) is characterized by warm temperatures and gentle, northerly monsoon winds that are accompanied by heavy rainfall associated with the southward migration of the Intertropical Convergence Zone (ITCZ). In the austral winter (May-Aug) the ITCZ shifts toward the equator, producing cool, dry conditions; winters are marked by strong south/south-easterly winds. Typically, the region experiences warm and dry conditions from September to November (Torrance, 1972; Patterson and Kachinjika, 1995).

The annual water budget reflects the highly sensitive hydroclimate of the catchment; approximately $62 \%$ of hydrologic inputs are from direct precipitation onto the lake surface (Spigel and Coulter, 1996). There are six major inflows to Lake Malawi (the Ruhuhu, Songwe, South Rukuru, Dwangwa, Bua, and Linthipe), located primarily along the northern and western margins (Patterson and Kachinjika, 1995). A steep north-south gradient exists with respect to annual rainfall (2400-800 $\mathrm{mm} \mathrm{yr}^{-1}$ ) and river discharge. Evaporation accounts for about $82 \%$ of annual water loss; the remaining water export is via the lake's only outlet, the Shire River, at its southern tip (Eccles, 1974; Spigel and Coulter, 1996). Seasonally, lake levels fluctuate several meters. A drop of $4 \mathrm{~m}$ would disconnect Lake Malawi from its outlet, closing the lake basin completely. This may have occurred as recently as the late 1800s (Hecky et al., 1996).

Lake Malawi is divided into three regions based on hydrographic and climatologic gradients (Gasse et al., 2002). The deepest part of the lake $(\sim 700 \mathrm{~m})$ is located in the central region; the northern region is generally shallower (maximum depth $\sim 600 \mathrm{~m}$ ), whereas the southern region is significantly shallower but has a greater surface area (Figure 1).

The modern lake is meromictic (never mixing completely); stratification is affected by both temperature and dissolved solids, which are both modified by hydrostatic pressure with depth (Wüest et al., 1996). During warm austral summers the density of the surface waters decreases, leading to the development of a well-defined seasonal thermocline; the well-mixed, low-nutrient epilimnetic waters usually are confined to the upper 50-80 m (Eccles, 1974; Patterson and Kachinjika, 1995). Surface water temperatures can rise up to $\sim 28^{\circ} \mathrm{C}$, reaching a maximum near the end of the rainy season. During the austral winter surface water temperatures fall to less than $\sim 24^{\circ} \mathrm{C}$. Together, the cooler waters and strong winter winds mix the epilimnion to a maximum depth of $\sim 125 \mathrm{~m}$ (Eccles, 1974; Vollmer et al., 2005). Ineffective transfer of energy with depth, the brevity of the windy season, and a weak chemical gradient keeps the modern lake stratified below $\sim 230 \mathrm{~m}$; temperatures in the hypolimnion remain between $22-23{ }^{\circ} \mathrm{C}$. Although there is some evidence of deeper mixing events in the past (Vollmer et al., 2005), today only about $20 \%$ of the metalimnetic water pool mixes with the epilimnion annually, while about $25 \%$ of the hypolimnion mixes with the metalimnion (Patterson and Kachinjika, 1995). During the winter season, strong southerly winds

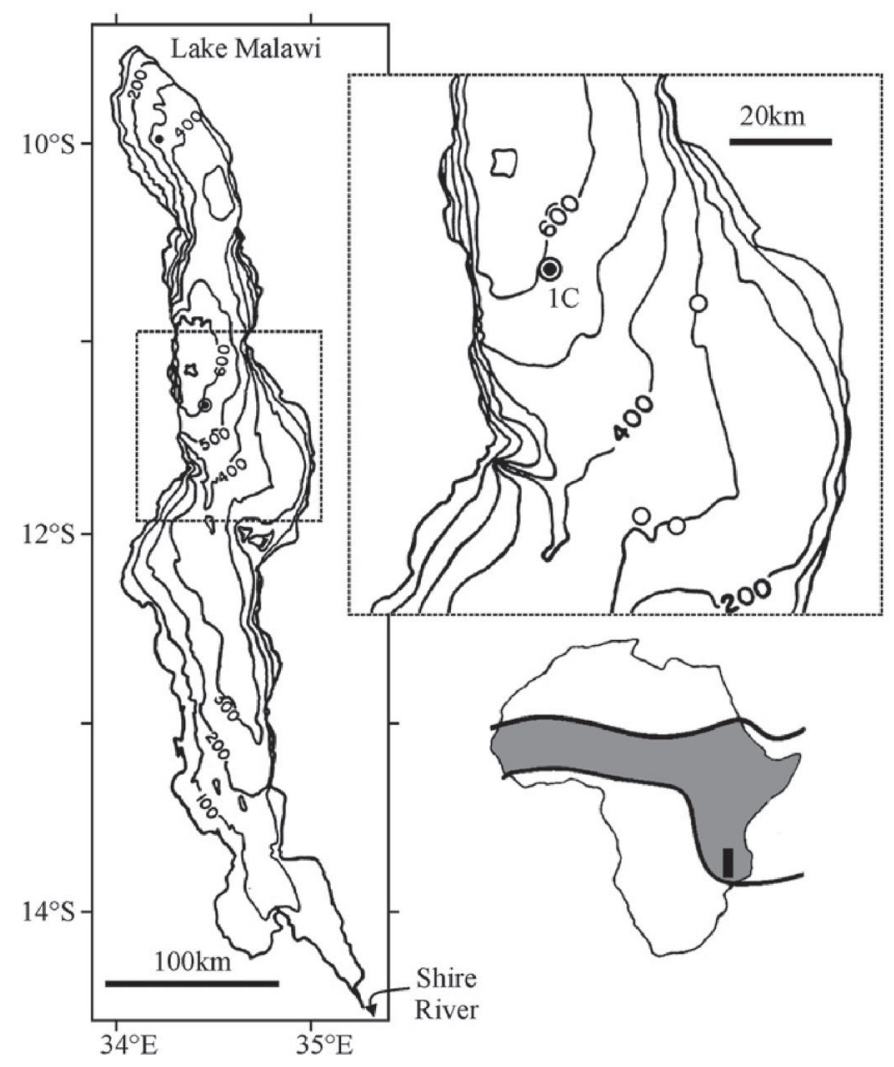

Figure 1. Location of the coring site Mal05-1C (double-circle). Shaded areas on the map of Africa indicate summer (southern) and winter (northern) limits of the ITCZ. Insets include bathymetric map of Lake Malawi and expanded bathymetry near the coring location. Core sites from Finney et al. (1996) are marked by open circles; Core Mal05-2A is marked by a filled circle in the northern basin. Bathymetric map modified from Finney et al. (1996).

stack water in the northern basin, effectively tilting the thermocline. In the southern basin, strong, cold dry winds enhance upwelling and chill surface waters through evaporative cooling.

The epilimnetic water is dilute $(\sim 235 \mu \mathrm{S} / \mathrm{cm})$, with a gradual increase in specific conductivity with depth (Patterson and Kachinjika, 1995; Wüest et al., 1996). The ionic composition of the lake is dominated by calcium, magnesium, sodium, and bicarbonate, which are leached from the metamorphic and igneous rocks of the drainage basin and delivered by inflowing streams (Patterson and Kachinjika, 1995). The epilimnion is characterized by a $\mathrm{pH}$ of $\sim 8.6$, which declines to circum-neutral conditions with depth. Below the epilimnion, silicic acid and dissolved gases increase with depth and help to maintain meromixis when the water column approaches isothermal conditions (Wüest et al., 1996). Dissolved oxygen declines steadily with depth to barely-oxic conditions at the metalimnion-hypolimnion boundary. Between 200-250 m, concentrations of dissolved oxygen are very low, and below $250 \mathrm{~m}$ the water is completely anoxic (Patterson and Kachinjika, 1995). Oxygen levels are mediated by the phytoplankton; in the epilimnion, photosynthesis dominates, leading to elevated $\mathrm{pH}$ and dissolved oxygen, while below the photic zone respiration dominates, leading to the anoxic conditions.

\subsection{Nutrient cycling and seasonal diatom succession}

The primary sources of biologically-available nutrients (silica, phosphorus, and nitrogen) to Lake Malawi include riverine influx (Si and $\mathrm{P}$ ), wet and dry atmospheric deposition ( $\mathrm{P}$ and $\mathrm{N}$ ), and biological N fixation (Hecky et al., 1996; Johnson, 2002; Bootsma et al., 2003). Nutrient retention is very high; nutrient 
exports via surface outflow are less than $5 \%$ of nutrient imports. Most of the annual nutrient losses occur either through sedimentation or atmospheric degassing. Cycling and vertical distribution of nutrients in Lake Malawi is strongly tied to the structure of the water column; nutrients tend to accumulate in the dark, anoxic hypolimnion where they are inaccessible to phytoplankton, while the epilimnion remains nutrient-poor, particularly during the summer when the seasonal thermocline is shallow and strongly developed (Eccles, 1974). The supply rate of nutrients (particularly Si and P) from rivers is determined by the rates of physical and chemical weathering in the surrounding catchment; however, annual influxes of Si and P are an order of magnitude smaller than the upward transfer of nutrients to the mixed layer through weak eddy diffusion mechanisms during the winter mixing season (Pilskaln and Johnson, 1991). Most of the annual $\mathrm{N}$ influx occurs through biological $\mathrm{N}$ fixation, but denitrifying bacteria living near the oxycline limit the potential availability of this nutrient in upwelling water (Hecky et al., 1996).

Diatoms are an important component of primary productivity in Lake Malawi. Diatoms often comprise a majority of the total algal biomass during the dry, windy austral winter season, but they tend to be rare throughout the remainder of the year because nutrients (particularly Si and P) are scarce in the welllit upper waters. Cyanobacteria and green algae dominate the phytoplankton during these periods (Patterson and Kachinjika, 1995). In the open waters of the central basin, primary productivity can increase substantially during the austral winter months as a result of vertical exchange of nutrients (primarily Si) that favor diatom growth (Haberyan and Mhone, 1991; Pilskaln and Johnson, 1991; Pilskaln, 2004). Far removed from diverse littoral habitats and inflowing rivers and characterized by restricted nutrient influx, the open waters of large deep lakes typically feature a low-diversity community dominated by diatom species in direct competition for seasonally-available nutrients (Kilham et al., 1986). Sedimentation of diatoms constitutes the primary sink for silica in the lake system (Johnson, 2002; Bootsma et al., 2003).

\section{Methods}

\subsection{Core recovery and chronology}

In 2005, Core Mal05-1C (hereafter Core 1C) was recovered from the central basin of Lake Malawi at a depth of $592 \mathrm{~m}$ as part of the Lake Malawi Scientific Drilling Project. The methods for core recovery and sampling are detailed in Scholz et al. (2011). The base of this $83 \mathrm{~m}$ core dates to ! $144 \mathrm{ka}$ and the sediments span the late Pleistocene continuously to the onset of the Holocene (10 ka). Sediment age was determined using several dating methods, including AMS radiocarbon, optically-stimulated luminescence (OSL), ${ }^{10} \mathrm{Be}$, and paleomagnetic stratigraphy. Age modeling did not involve "tuning" to any external chronologies. Details regarding chronological control are provided in Scholz et al. (2007) and Brown et al. (2007), and discussed in detail in Scholz et al. (2011).

\subsection{Diatom analytical methods}

Four hundred and seventy-one samples were collected from Core 1C for diatom analysis; discrete, 1-cm samples were taken every $16 \mathrm{~cm}$. Each sample was treated with $10 \% \mathrm{HCl}$ and $35 \%$ $\mathrm{H}_{2} \mathrm{O}_{2}$ at room temperature to digest carbonate and organic material. Clay-rich samples were briefly immersed (15-30 s) in an ultrasonic water bath and mechanically agitated to disaggregate the sample; no evidence of frustule damage was detected. Known quantities of polystyrene microspheres were added to estimate diatom concentrations (Battarbee, 1986); diatoms were mounted in Zrax, a high-refractive index medium.

Diatom frustules were identified to the highest taxonomic level possible with $1000 \times$ magnification light microscopy. Tax- onomic identification follows primarily from studies of East African diatoms, including the seminal publications of Müller $(1903,1904,1905,1910)$, and more recent contributions from Gasse (1980, 1986), Cocquyt et al. (1998), Klee and Casper (1992, 1996), and Kociolek and Stoermer (1990), with additional reference to the taxonomic collections of Krammer and Lange-Bertalot (1986-1991) and Krammer (2003); recent generic combinations were applied to all taxa. When possible, at least 300 diatom valves were identified from each sample interval; eight highlydissolved or low-abundance samples, with fewer than 100 diatom valves counted, were excluded from all statistical analyses.

Characterization of the fossil diatom assemblage also employed a stratified enumeration strategy for Aulacoseira species. After the initial counts for each slide were completed, counting of Aulacoseira taxa continued until, when possible, at least 300 Aulacoseira valves were identified from each sample. Although this enumeration strategy typically is used to reveal populations obscured by dominance, here it was used to provide a better understanding of the nature of meroplanktic transitions in fossil assemblages through time. Samples with fewer than 100 Aulacoseira valves counted were excluded from statistical analyses of the stratified dataset $(n=452)$.

\subsection{Wet-sieved residue methods}

Sediment samples were disaggregated (in DI water only, or when required, by a freeze-thaw cycle) and washed in DI water using a $125-\mu \mathrm{m}$ stainless steel sieve. A second aliquot of the same sample was weighed, oven dried, and reweighed, to determine water content. Wet-sieved residues were analyzed for total number of ostracodes per sample (adjusted to abundance/ gm using dry weight calculations), taphonomic condition, percentage adult, and percentage major genera based on 100 valve counts, using an Olympus SZH binocular microscope. Additional data collected from the wet-sieved residue included absolute abundance of chaoborid fragments and relative abundance of minerals in the sand fraction.

\subsection{Data screening and multivariate analysis}

Prior to statistical analysis, we removed taxa that did not occur in at least three samples in abundances of $1 \%$ or more from both stratified (Aulacoseira only) and unstratified diatom datasets. Following screening, the stratified and unstratified datasets included 33 and 73 diatom taxa, respectively. The 73 taxa of the unstratified dataset represent between 89 and $100 \%$ of the total assemblage of each sample. No taxa were excluded from the stratified dataset. Zonation of the diatom record is based on stratigraphically-constrained cluster analysis (CONISS) of the unstratified dataset (Figure 2). Relative abundance data were square-root transformed prior to cluster analysis using PSIMPOLL 4.10 (Bennett, 2002). Determination of the number of zones (12) was subjective, however, all designated zones and sub-zones are significant (broken-stick model; Bennett, 1996). Zones are numbered M1 to M12; additional sub-zones 5A-5C were designated based on significant clusters from the unstratified counts (Figure 3). Zonation of the stratified, Aulacoseira-only dataset, matches closely to zonation of the unstratified dataset.

In order to numerically examine diatom indicators in combination with other indicators of hydrographic variability, we performed principal components analysis (PCA); this analysis included the relative abundance of major diatom groups (detailed below), relative abundance of major ostracode groups, percentages of vivianite, terrigenous minerals, and carbonatecoated grains, and log-concentrations of chaoborid fragments and ostracode valves (Figures 4 \& 5). PCA of 18 variables and 438 samples was performed using CANOCO 4.5 (ter Braak and Šmilauer, 2002); variables were centered and standardized but otherwise untransformed. PCA scores were re-sampled to 200yr intervals and smoothed by singular spectrum analysis, using AnalySeries 1.2 (Paillard et al., 1996). 


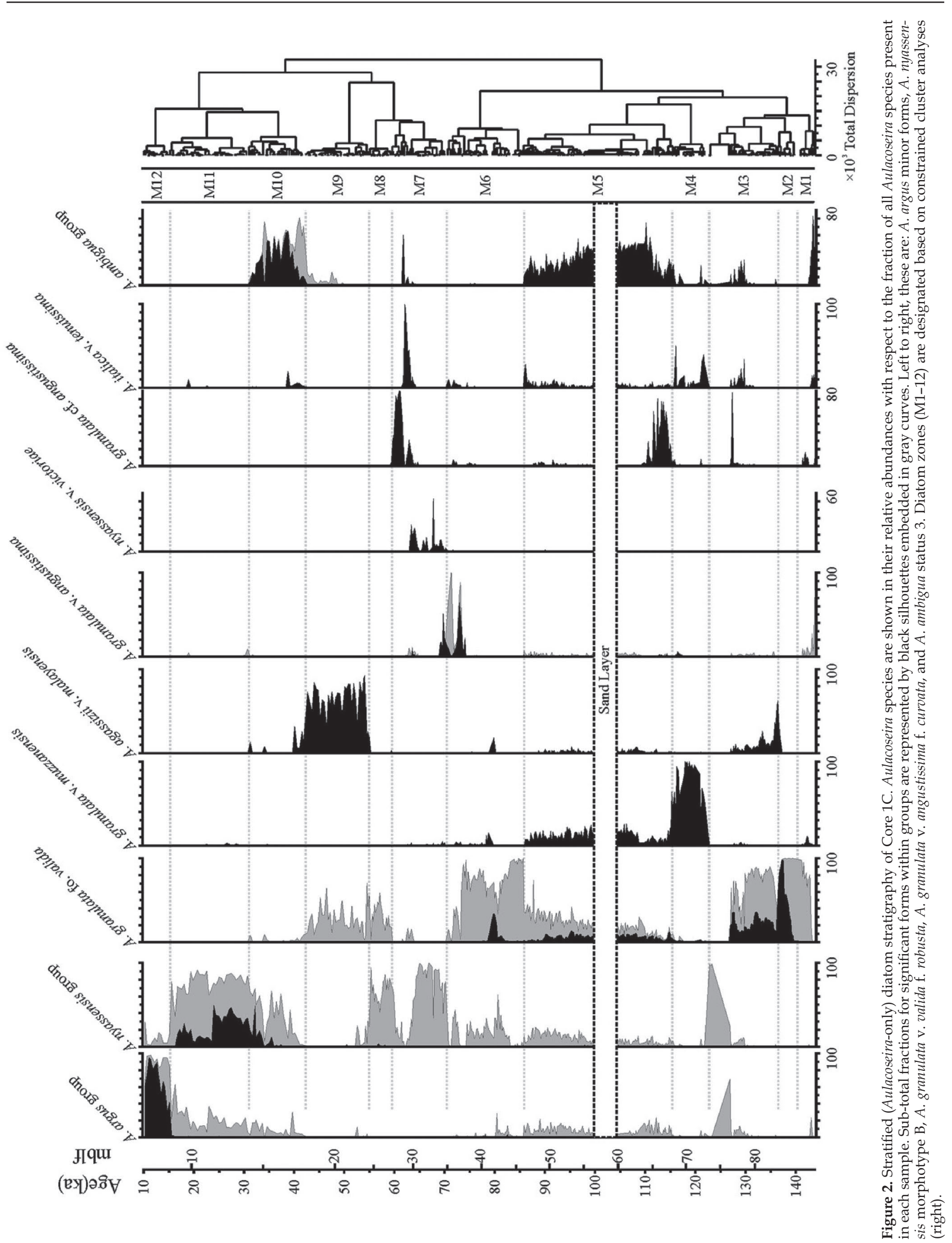




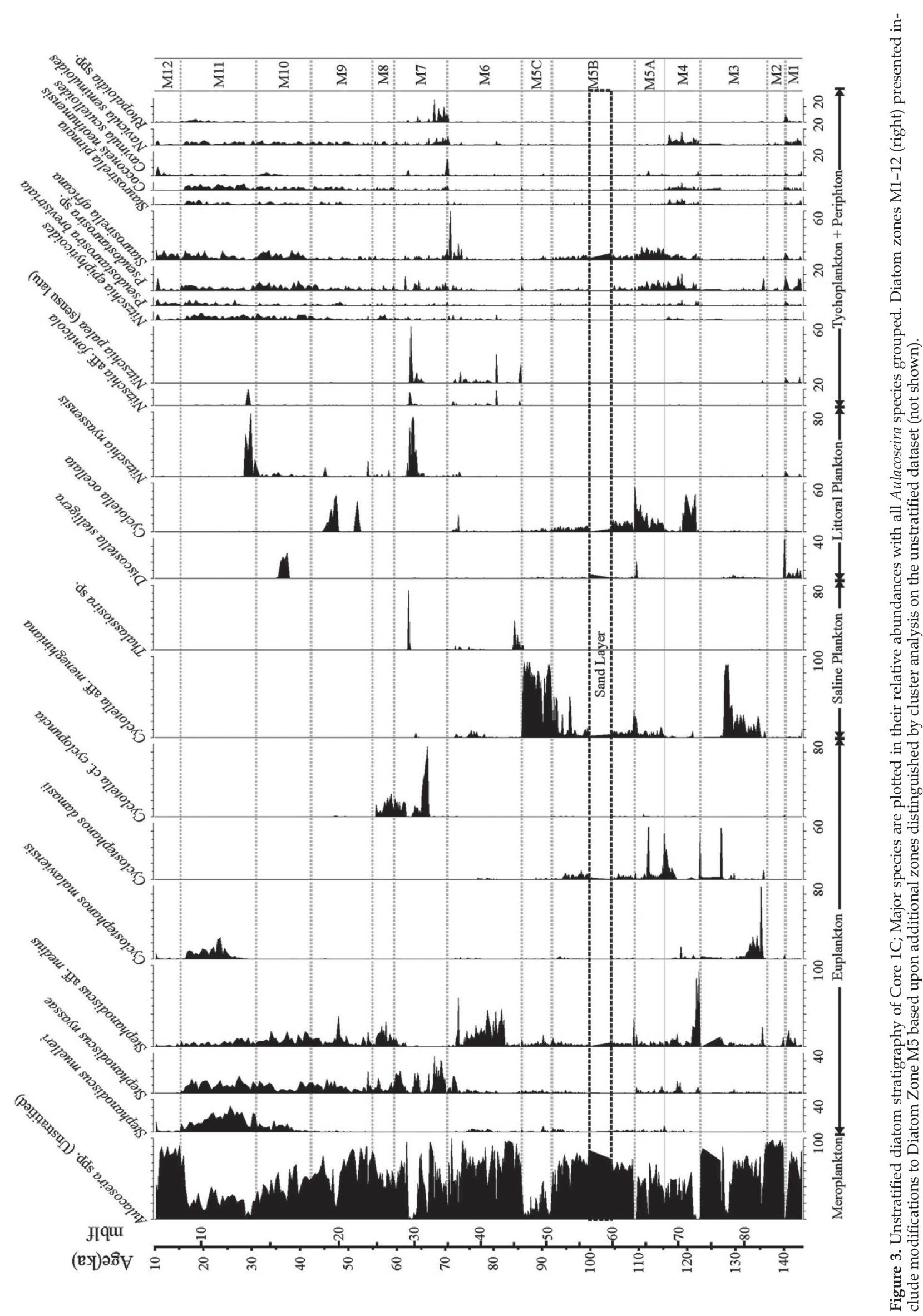




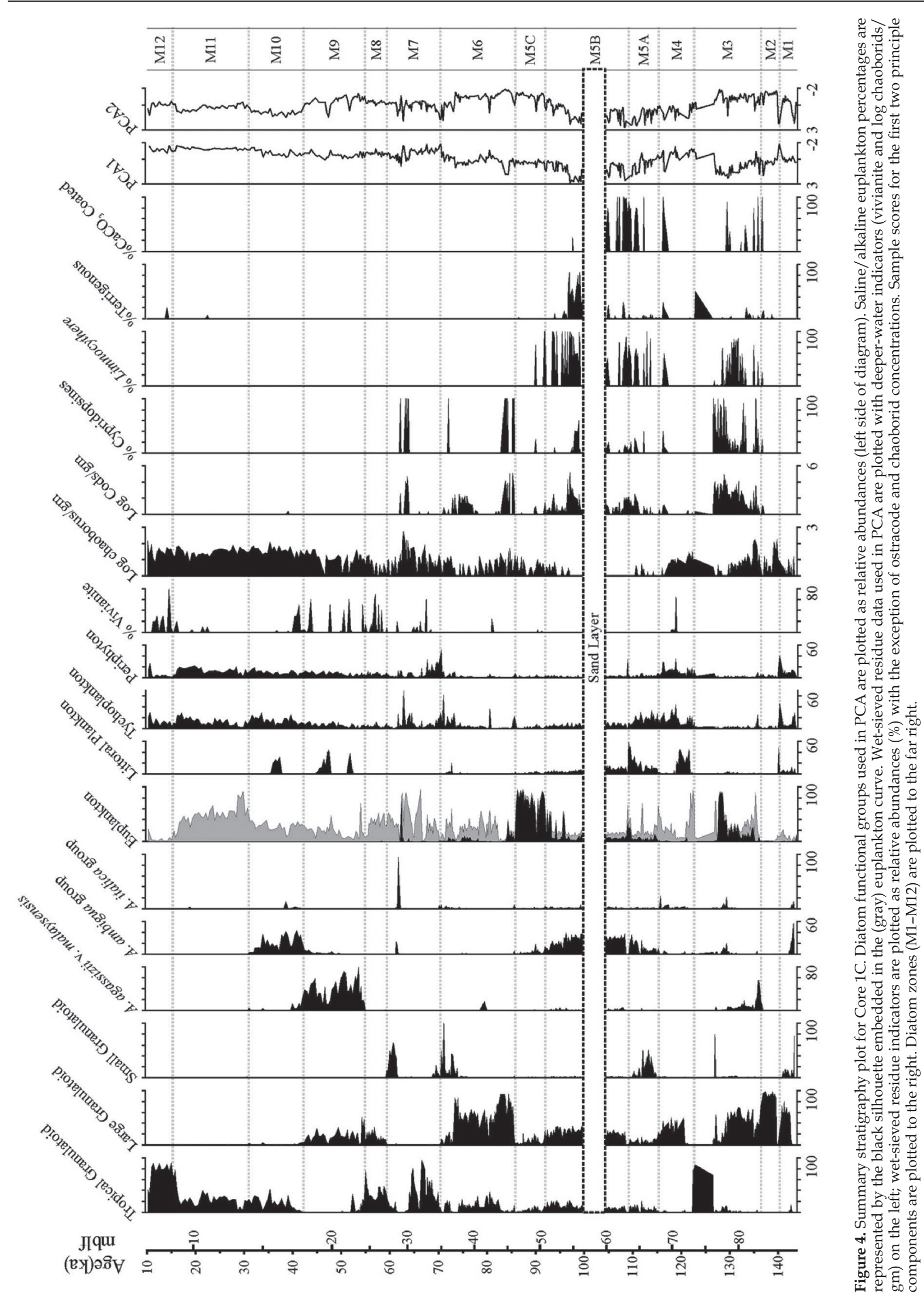




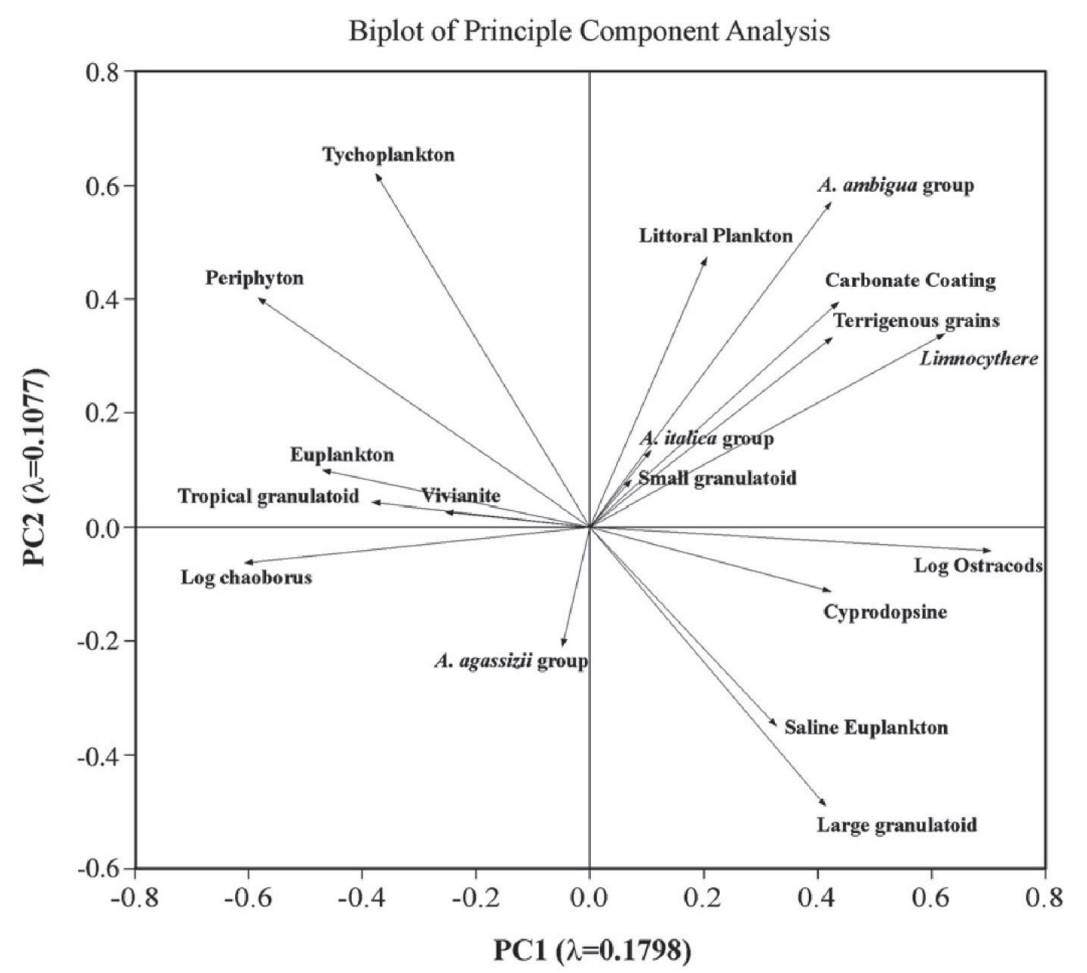

Figure 5. Eigenvector plots of indicator variables along the first two ordination axes (principal components). Each arrow points in the direction of increasing values of the corresponding variable. Arrows that point in the same direction are positively correlated, perpendicular arrows are uncorrelated, and arrows that point in opposite directions are negatively correlated. The length of an arrow reflects the strength of the correlation to the principal component. Eigenvalues for each principle component indicated in parentheses correspond to percentage of variance explained. Maximum variance in the dataset (PC1) is interpreted to correspond to changes in lake depth; highly-positive values are associated with shallowwater and saline/alkaline indicators, while highly-negative values are generally associated with deeper-water indicators.

\section{Results and interpretation}

\subsection{Diatom taxonomy, ecology and paleoecological implications}

Lacustrine diatoms inhabit a wide array of environments and employ many different ecological strategies. In deep open water, the absence of available substrates within the photic zone limits possible successful diatom life strategies to a smaller subset of functionally-planktic groups: euplankton, meroplankton, tychoplankton, and epiphyton living upon phytoplankton.

Euplanktic diatom species may live in colonies or as solitary cells, but they are always free-floating. Typically, euplanktic diatoms can only persist if at least part of the population is able to keep from sedimenting into the hypolimnion. Because their frustules have a greater silicate mass, large euplanktic diatoms generally are denser than smaller diatoms, and as a result, they tend to sink at much faster rates. Consequently, turbulence in the epilimnion or deeper light penetration is required to maintain populations of larger-diameter euplanktic diatoms (Huisman and Sommeijer, 2002). During periods of low turbulence, some euplanktic species may persist near the base of the thermocline, where denser waters with elevated nutrient concentrations may help keep them from completely sedimenting out of the water column (Tilman and Kilham, 1976).

In contrast, meroplanktic diatom species typically have very dense frustules, live in colonies, and are adapted to persist for long periods in dark, anoxic conditions of the hypolimnion (Jewson, 1992); they exist as plankton only when there is significant upwelling or turbulence to keep them suspended in the water column. Often meroplankton reproduce very rapidly and have a distinct competitive advantage over other plankton when nutrients are not limiting growth. In meromictic lakes, this reproductive strategy is particularly effective because increased turbulence is almost always associated with increased nutrient flux from the hypolimnion. Meroplankton are incapable of maintaining abundant populations in the water column once turbulence and nutrient concentrations diminish because of their dense frustules and high nutrient requirements (Kilham, 1990). During periods of insufficient mixing strength, meroplanktic diatoms are capable of persisting for several years (or longer) on the sediment-water interface by encysting (Sicko-Goad et al., 1986; Jewson, 1992).

Tychoplankton include species that can live either in shallow, well-lit benthic habitats, in floating algal mats, or entrained in the water column as plankton. Their existence in deep, open water environments generally requires transport from (or greater proximity to) nearshore environments (Gasse et al., 2002).

Currently, the deep-basin open waters of Lake Malawi are dominated by three major diatom groups: stephanodiscoid species (as used here, species from the genera Stephanodiscus and Cyclostephanos), Aulacoseira, and Nitzschia (Owen et al., 1990; Owen and Crossley, 1992; Patterson and Kachinjika, 1995). In a given winter season, species from any of these groups may dominate, but analyses of plankton tows and sediment traps suggest that they often follow a repeating, regular seasonal succession, which is dictated by the seasonal strength of mixing and the resultant progressive change in nutrient concentration in the epilimnion (Hecky and Kling, 1987; Pilskaln and Johnson, 1991; Pilskaln, 2004). Diatoms that are not found commonly in the deep open waters of the central basin today are often substantial components of the fossil diatom assemblages from Core 1C; the known ecology of the dominant taxa and our interpretation of these assemblages are discussed below.

\subsubsection{Stephanodiscus and Cyclostephanos species}

The stephanodiscoid species in Lake Malawi are typically euplanktic (although some may be meroplanktic). Stephanodiscoid species generally have moderately high $\mathrm{P}$ and moder- 
ately low Si nutrient requirements (Owen and Crossley, 1992). In Lake Malawi, stephanodiscoid species often are the dominant deep-water phytoplankton throughout the lake during the early (and sometimes late) austral winter. The timing of seasonal blooms is part of a regular diatom successional pattern that is directly tied to the thermal structure of the lake. During early winter, strong, cool south-southeasterly winds blow over the surface of the lake. Cooling increases the density of the epilimnetic water and leads to mixing of surface waters to greater depths; this results in an increased vertical flux of $\mathrm{P}$ and Si from the hypolimnetic nutrient pool, enriching the well-lit surface waters. Stephanodiscoid species thrive in the earlier (and later) winter season because the nutrient flux and turbulence is sufficient to maintain their populations, but not high enough to suspend or maintain significant populations of meroplankton (specifically, Aulacoseira) (Haberyan and Mhone, 1991). As the water continues to cool and the winds persist, the epilimnion deepens, which increases the vertical flux of silica. This creates favorable conditions for Aulacoseira, which quickly out-compete the stephanodiscoid species for available nutrients (Kilham et al., 1986; Hecky and Kling, 1987). Near the termination of the windy season, Si flux often decreases producing conditions where stephanodiscoid species become dominant again. Although the reason is unclear, in some winter seasons significant meroplankton blooms do not occur (Hecky and Kling, 1987; Patterson and Kachinjika, 1995).

Stephanodiscoid species are a major component of the fossil diatom assemblages during the late Pleistocene, although they are persistently more abundant after $31 \mathrm{ka}$ and dominate only during brief intervals before $31 \mathrm{ka}$ (Figure 3). Based on the ecology of the modern lake, we interpret intervals of stephanodiscoid dominance in fossil assemblages as periods when flux of $\mathrm{Si}$ to the epilimnion was suppressed; this may represent either persistently shallow seasonal mixing depths or a net depletion of biologically-available $\mathrm{Si}$ in the hypolimnetic nutrient pool (Hecky et al., 1996; Johnson, 2002).

Two small-diameter species, Stephanodiscus nyassae Klee \& Casper and Stephanodiscus aff. medius (following Gasse et al., 2002), are present at low abundances (5-15\%) throughout the core. Other species, including Stephanodiscus mulleri Klee \& Casper, Cyclostephanos malawiensis Casper \& Klee, and Cyclostephanos damasii (Hustedt) Stoermer \& Håkansson, tend to occur as a dominant component of fossil assemblages in discrete horizons (Figure 3). Very little is known about the autecology of stephanodiscoid taxa from Lake Malawi, partly due to taxonomic uncertainties surrounding S. nyassae, S. muelleri, and C. malawiensis, which were described relatively recently (Klee and Casper, 1992, 1996).

When large stephanodiscoid species, such as $S$. muelleri and C. damasii dominate the fossil record, we infer an environment that is relatively similar, hydrographically, to the modern lake, i.e., clear and sufficiently turbulent to maintain larger euplanktic forms in deep water. These species are often the dominant forms reported from the open waters of the modern lake (Hecky and Kling, 1987; Patterson and Kachinjika, 1995); when smaller stephanodiscoid forms dominate, this may be an indication of decreased turbulence or perhaps increased turbidity of the surface waters (Huisman and Sommeijer, 2002).

\subsubsection{Aulacoseira species}

Typically, Aulacoseira are meroplanktic organisms. As discussed above, periods of Aulacoseira dominance are a product of enhanced mixing, creating an upward flux of Si from the hypolimnion. As turbulence decreases and nutrient upwelling diminishes towards the end of the austral winter, Aulacoseira rapidly sink out of the water column (Kilham et al., 1986; Haberyan and Mhone, 1991; Jewson, 1992). The downward flux of Aulacoseira filaments often form dense "sticky mats" (sometimes referred to as marine snow), which can act to clarify the water column and force the sedimentation of euplanktic species, increasing the ex- port of biologically-available silica to the hypolimnion (Ryves et al., 2003; Pilskaln, 2004). Many Aulacoseira species form resting cells when not actively reproducing. During subsequent periods of mixing or upwelling, these resting cell valves are often resuspended and can act as inoculum for the next growing season (Sicko-Goad et al., 1986; McQuoid and Hobson, 1996).

In the central basin sediments, Aulacoseira species were a major constituent of nearly every sample (Figure 2); approximately $92 \%$ of the samples analyzed contained greater than 10\% Aulacoseira, and $57 \%$ of the samples contained greater than $50 \%$ Aulacoseira. However, substantial intrageneric changes occur throughout the late Pleistocene. For example, the dominant Aulacoseira taxa in Core $1 \mathrm{C}$ prior to $70 \mathrm{ka}$ are rarely found in the deep waters of the central basin today, but are observed commonly in the shallower, well-mixed southern basin (Owen et al., 1990; Owen and Crossley, 1992).

A diverse assemblage of Aulacoseira species were observed in the core, including 33 distinct forms, separated to species, variety, and morphotypic levels, when possible. These forms were grouped into six Aulacoseira species complexes for inclusion in PCA: tropical granulatoid, large granulatoid, small granulatoid, A. agassizii v. malayensis (Hustedt) Simonsen, A. ambigua (Grunow) Simonsen, and A. italica (Ehrenberg) Simonsen (see Appendix A for a detailed discussion of the Aulacoseira taxonomy).

Aulacoseira nyassensis (O. Müller) Simonsen was initially described from Lake Malawi, and it is considered a deep freshwater tropical species common to many of the large lakes of East Africa. It is especially abundant in the modern plankton during the austral winter and in sediments recovered from the northern and central basins of Lake Malawi. The taxonomy of A. nyassensis in Core $1 \mathrm{C}$ is complex and includes multiple closely-related forms, which are grouped here for simplicity of discussion (see Appendix A for further explanation). Aulacoseira nyassensis forms were often found coincident with occurrences of a closelyrelated (and possibly endemic) form, Aulacoseira argus (O. Müller) Simonsen. Aulacoseira argus is a very large-diameter species with large pores that is also found primarily in the deeper waters of Lake Malawi (Müller, 1904). Because of their morphological similarity to Aulacoseira granulata and their occurrence being restricted to tropical lakes, we have labeled these taxa as "tropical granulatoid" diatoms. Due to taxonomic uncertainties, some forms identified as belonging to the $A$. nyassensis v. victoriae $(\mathrm{O}$. Müller) Simonsen complex were excluded from this group.

Sixteen distinct forms belonging to the Aulacoseira granulata complex were identified. These include large-diameter forms such as $A$. granulata v. muzzanensis (Meister) Simonsen and $A$. granulata fo. valida (Hustedt) Simonsen, and smaller-diameter forms such as A. granulata v. angustissima (Müller) Simonsen. The A. granulata complex is broadly considered a cosmopolitan freshwater group, common in shallow lakes, rivers, and marginal regions of larger lakes (Kilham and Kilham, 1975). In modern Lakes Malawi and Tanganyika, it is abundant only where the waters are shallower, well mixed, and upwelling is enhanced (Haberyan and Mhone, 1991; Owen and Crossley, 1992).

Aulacoseira agassizii v. malayensis is also closely related to $A$. granulata but is distinguished morphologically by a substantially larger diameter, the nature of the areolae on the mantle, and the frequency of linking spines. It occurs in Lake Malawi, but only in abundance in the southern basin (Owen et al., 1990; Owen and Crossley, 1992). Aulacoseira ambigua is a fine-pored, small diatom that is common in shallow lakes or the shallow margins of larger lakes in East Africa (Gasse, 1986; Barker et al., 2003). It is found today in the plankton of the southern basin (Owen and Crossley, 1992). Aulacoseira italica v. tenuissima (Grunow) Simonsen is a narrow, fine-pored taxon common is shallow alkaline lakes (Gasse, 1986). In the central basin sediments, this species is often present at background levels and occasionally peaks dramatically in discrete horizons. Aulacoseira italica v. tennuissima consistently occurs when $A$. ambigua is also abundant. 
We interpret sample intervals dominated by Aulacoseira to indicate periods when enhanced winter mixing resulted in an increase in vertical nutrient flux and enhanced turbulence, which inhibited the sinking of meroplankton. Further, we assume that because species belonging to the "tropical granulatoid" group are prevalent today, dominance by these Aulacoseira indicate ecologically-similar conditions to the modern central and northern basins (i.e., deep, low-nutrient, dilute water) and that dominance by Aulacoseira species common in the shallower, wellmixed southern basin likely represents a substantial departure from the modern central basin environment (Kilham, 1990; Owen et al., 1990; Haberyan and Mhone, 1991; Owen and Crossley, 1992).

\subsubsection{Nitzschia species}

Nitzschia species occur in a diverse array of habitats as euplankton, littoral plankton, tychoplankton, epiphyton, or periphyton. In modern Lake Malawi, planktic Nitzschia species can be a major component of the seasonal succession, often blooming after Aulacoseira. Nitzschia species respond favorably to rapid influxes of $\mathrm{Si}$, particularly when $\mathrm{P}$ is moderately low (Haberyan and Mhone, 1991) but are often found in the modern environment during periods of low turbulence, along with nitrogen-fixing bacteria (Patterson and Kachinjika, 1995).

Nitzschia species are relatively infrequent in the fossil assemblages of Core $1 \mathrm{C}$, occasionally dominating discrete horizons after $70 \mathrm{ka}$ (Figure 3). This may partly be a consequence of preferential dissolution of Nitzschia frustules; many species are lightly silicified and one study from Lake Malawi found lower abundances of Nitzschia in the sediments than in the overlying water column (Haberyan, 1990). We interpret periods dominated by planktic Nitzschia to represent low nutrient conditions, probably as a result of decreased turbulence.

Several of the Nitzschia species found in the late Pleistocene record from Core $1 \mathrm{C}$ may be tychoplanktic or epiphytic. For example, Nitzschia epiphyticoides Hustedt has been found in abundance growing on Aulacoseira valves (particularly A. nyassensis) in Lake Malawi (Haberyan and Mhone, 1991); we associate increased abundance of these taxa after $70 \mathrm{ka}$ with the increased abundances of deep-water meroplankton with which they co-occur.

\subsubsection{Cyclotelloid and Thalassiosira species}

Although many taxa belonging to these genera are relatively rare in the modern lake environment, planktic cyclotelloid (Cyclotella, Discostella) and Thalassiosira species are a significant component of the Malawi fossil record prior to $\sim 35 \mathrm{ka}$ (Figure 3). When abundant, these species are probably replacing stephanodiscoid species as the dominant euplankton. In other modern systems, cyclotelloid species commonly thrive in lowto-very low nutrient environments. Recently, multiple limnological studies in arctic and temperate environments across North America and Europe have noted a marked shift in diatom communities that were previously dominated by Fragilaria or $\mathrm{Au}$ lacoseira towards dominance by cyclotelloid taxa (Tolotti et al., 2007; Ruhland et al., 2008; Winder and Hunter, 2008). In these studies, the observed shifts are attributed to decreased nutrient upwelling (especially in meromictic lakes) driven by enhanced stratification associated with recent warming trends. Although large East African tropical systems cycle nutrients in a substantially different way than temperate lakes (Hecky et al., 1996) and cyclotelloid species are rare in Lake Malawi today, we believe the general inference that cyclotelloid species represent low nutrient (particularly low P) environments is applicable to cyclotelloid-dominated fossil diatom assemblages from Core 1C.

Discostella stelligera (Cleve \& Grunow) Houk \& Klee and Cyclotella ocellata Pantocsek are often considered littoral or facultative plankton, sometimes with affinities for elevated alkalinity (Gasse, 1986). Both species are considered cosmopolitan and are found throughout the world in very low nutrient environments today (Tolotti et al., 2007; Winder and Hunter, 2008; Winder et al., 2008). Occurrences of both are also cited as evidence of widespread increases in stratification (Ruhland et al., 2008). Neither species has been reported in abundance from the modern phytoplankton communities of Lake Malawi; a few reports of $C$. ocellata exist from recent sediments from shallow parts of the southern basin, but always occurring as less than $25 \%$ of the fossil diatom assemblage (Owen and Crossley, 1992; Owen et al., 1990). Here we interpret their abundance in the sediment of Core $1 \mathrm{C}$ as representing low-nutrient planktic environments, higher alkalinity, and, potentially, increased proximity to littoral habitats and have classified them as "littoral plankton." The autecology of the species Cyclotella cf. cyclopuncta is unknown, but it is likely euplanktic and, when abundant, we infer relatively low-nutrient conditions. The C. cf. cyclopuncta and D. stelligera forms observed in the sediment archives of Lake Malawi are often considerably larger than $C$. ocellata and may represent elevated turbulence or water clarity by comparison (Huisman and Sommeijer, 2002; Winder et al., 2008).

Prior to $85 \mathrm{ka}$, the euplankton is often dominated by an undescribed species belonging to the Cyclotella meneghiniana complex (hereafter Cyclotella cf. quillensis). This taxon (Julius et al., in preparation) shares features with C. meneghiniana Kützing and C. quillensis Bailey, but which can be easily distinguished from both species in light microscopy by size, arrangement of central fultoportulae, and a lack of transverse undulation on the valve face. All taxa belonging to the C. meneghiniana complex, and particularly C. quillensis (to which this species is probably most closely related), share an affinity for cation-rich waters. In large lakes, C. meneghiniana and related forms commonly thrive where salinity fluctuates rapidly between fresh and brackish conditions (Hecky and Kilham, 1973; Tuchman et al., 1984; Gasse, 1986). An undescribed Thalassiosira species (hereafter Thalassiosira sp.), which often co-occurs with $C$. cf. quillensis, is found in significant abundances at $\sim 85$ and $\sim 62 \mathrm{ka}$. Thalassiosira species have been found in abundance, together with $C$. quillensis or C. meneghiniana, in tropical East African lakes characterized by saline and alkaline water (Hecky and Kilham, 1973; Gasse, 1986). On this basis we have classified Cyclotella cf. quillensis and Thalassiosira sp. together as "saline/alkaline euplankton."

Dominance of fossil assemblages by saline/alkaline euplankton suggests a lacustrine environment very different from the dilute epilimnion and gradual salinity gradient that characterizes the central basin today. Such a substantial change in lake chemistry indicates a persistently-closed basin, which is likely to have had a profound influence on mixing and nutrient cycling regimes. Hecky et al. (1996) postulated that through evaporative concentration a persistently-closed Lake Malawi would experience an increase in the salinity of the surface waters during cool, windy winters; this would increase the density of the epilimnetic waters and greatly enhance vertical mixing of the water column. The short-term effect would be to enhance nutrient upwelling, inducing higher diatom productivity, and likely increasing the dominance of meroplanktic species. However, the hypolimnetic nutrient pool is not limitless and biologicallyavailable Si and P fluxes to Lake Malawi are proportionately small and likely to decrease with increased aridity. Thus, extended strong seasonal mixing would eventually lead to a substantial decrease in nutrient availability (Johnson, 2002; Bootsma et al., 2003). Prolonged aridity would have resulted in a significantly shallower, well-mixed, and nutrient-poor Lake Malawi.

Under a humid climate following arid periods (lake refilling phases), rising lake levels would probably be accompanied by increasing disparity between dilute surface waters and saline hypolimnetic waters. Initially, this would result in a chemically-stratified lake that would be highly resistant to deep mixing. However, during prolonged refilling phases, ionic concentrations would eventually become distributed more evenly, producing a weak chemical gradient similar to the gradient observed today. We interpret the presence of saline- and alkaline- 
tolerant euplankton in fossil diatom assemblages to be indicative of a substantially more arid climate than today; however, we contend that dominance of saline/alkaline euplankton is more likely indicative of relatively humid, lake refilling phases, where the chemical disparity between the epilimnion and hypolimnion is most pronounced, enhancing stratification and suppressing Si upwelling to favor cyclotelloid species over meroplankton during the windy season.

\subsubsection{Tychoplanktic and Periphytic species}

The deep central basin of modern Lake Malawi is quite distant from littoral habitats. As a result, fossil diatom assemblages from Core $1 \mathrm{C}$ rarely show large fractions of periphytic (attached benthon) and tychoplanktic species (Figure 3). Tychoplanktic species present in fossil assemblages are most commonly represented by the colonial fragilarioid species Staurosirella africana (Hustedt) D. M. Williams \& Round, Staurosirella pinnata (Ehrenberg) D.M. Williams \& Round, Pseudostaurosira brevistriata (Grunow in Van Heurck) D.M. Williams \& Round, and one unidentified species complex probably belonging to the genus Pseudostaurosira (see Gasse et al., 2002, "Fragilaria af. pinnata"). Biraphid tychoplanktic and periphytic forms observed in relatively low abundances throughout the late Pleistocene of Lake Malawi include Cavinula scutelloides (Smith) Lange-Bertalot \& Metzeltin, Cocconeis neothumensis Krammer, Navicula seminuloides Hustedt, and Rhopalodia aff. constricta.

Commonly, an increase in abundance of species that inhabit shallow water in fossil diatom assemblages, particularly from cores recovered from deep water sites, is interpreted as evidence of lower lake levels. In a shallower lake, the transport distance from littoral habitats to the deep basins is reduced, which increases the proportion of periphyton to phytoplankton preserved in deeper water sediments through the process of sediment focusing (Wolin and Duthie, 1999; Gasse et al., 2002). However, transport mechanisms that produce varved sediment in the northern basin of Lake Malawi have been linked to offshore redistribution of silts and clays through benthic nepheloid plumes; these plumes are capable of transporting sediment long distances into the basin and are probably closely related to annual rainfall and river flood loading (Johnson and McCave, 2008). Because diatoms are a silt-sized component of the sediment, it is likely that their transport into the deeper basins is directly affected by this process. This process is also likely to be more significant in a large open-basin system than the standard sediment focusing mechanisms assumed in small closed-basin systems, given the long transport distances required. Additionally, the proportion of available benthic habitat can change substantially with rising or falling lake levels, and as a result, the relationship between falling lake levels and increased proportion of benthic habitat area available is not always simple (Stone and Fritz, 2004). To be cautious, we interpret changes in the abundance of tychoplanktic and periphytic taxa in the fossil diatom assemblages from Core $1 \mathrm{C}$ to represent periods when water levels were fluctuating (i.e., constant lake depths would likely produce relatively constant influxes of these forms into the deep basin) rather than assuming a clear directional change with lake depth.

\subsection{Wet-sieved residue analysis}

The paleohydrographic reconstruction of Lake Malawi also draws upon evidence from wet-sieved sediment samples collected from the same horizons as analyzed for diatoms (Figure 4). The wet-sieved residue information is used to infer paleoenvironmental settings and constrain estimates of past lake level.

\subsubsection{Ostracodes and chaoborids}

Fossil ostracodes observed in the wet-sieved residue were exclusively benthic fauna incapable of surviving in persis- tently-anoxic habitats (Cohen et al., 2007). Modern hydrographic studies of Lake Malawi place the oxycline $\sim 250 \mathrm{~m}$ below the lake surface (Patterson and Kachinjika, 1995); below this the water is undersaturated with respect to calcium carbonate. Because of these physical and ecological restrictions, we interpret the presence of abundant ostracode fossils in the sediment to require lake levels that are significantly shallower than those observed in the modern central basin, with maximum water depths at the coring site probably no greater than $\sim 250 \mathrm{~m}$.

Between 133-130 ka and 118-90 ka fossil ostracode assemblages are characterized by low diversity, high adult/juvenile ratios, carbonate coatings, and dominance by Limnocythere species, which are indicative of saline or alkaline environments. We interpret these fossil ostracode assemblages as evidence of very shallow, littoral conditions; because the valves are fragile and often show signs of decalcification, significant transport can be discounted; this is corroborated by their common association in the sediment record with peak abundances of texturally-clean, coarse-grain terrigenous material (Figure 4).

From 90-62 ka, ostracode assemblages are often dominated by weakly-calcified endemic cypridopsine ostracodes (Figure 4). We interpret the high concentration of juvenile ostracodes found in the sediment as indicative of a stressed, deeperwater (though still less than $\sim 250 \mathrm{~m}$ ) benthic environment (Palacios-Fest et al., 2005; Park et al., 2003). The relationship between deep, quiet-water, dysaerobic environments and the abundance of juvenile-dominated assemblages is well established in other systems and the preservation of whole fragile valves eliminates the likelihood of significant transport (Brouwers, 1988; Whatley, 1988).

Chaoborid fragments are present in high concentrations in Core $1 \mathrm{C}$ prior to $\sim 120 \mathrm{ka}$ and after $\sim 90 \mathrm{ka}$ (Figure 4 ). Within this interval, chaoborid fragments are present in very low concentrations or absent. Chaoborids often escape predators by migrating into anoxic and/or low-light, deepwater habitats, and we associate abundant concentrations of their fossils in Core 1C with anoxia at the core site (Cohen et al., 2007). This interpretation is generally reinforced by an inverse relationship between ostracodes and chaoborid fragment abundance throughout the core; where fossils of both organisms are found together in moderate proportions we interpret the oxycline was nearly coincident (at least seasonally) with the lake floor at the coring site.

\subsubsection{Vivianite and terrigenous Grains}

Cohen et al. (2007) reported that vivianite crystals found within the wet-sieved residue occur in randomly oriented clusters, suggesting formation at or near the sediment-water interface. Reduced iron and phosphate are required for the formation of vivianite crystals and the mineral is commonly found forming today in Lake Malawi under sustained reducing conditions. In Core $1 \mathrm{C}$, vivianite abundance has an inverse relationship with coarse-grained terrigenous material and ostracode concentrations in the wet-sieved residue (Figure 4). We interpret increased abundance of vivianite to indicate relatively deep water environments with lake-floor anoxia above the core site.

Sand layers are well-sorted and texturally clean. Sand-rich layers occur in centimeter-decimeter scale, ungraded, and mottled beds; they exhibit features typical of shallow-water deposition, including deep burrowing and carbonate-coated grains $\left(\mathrm{CaCO}_{3}\right.$ ooids); when sands are abundant, other indicators of shallow, alkaline conditions are persistent stratigraphically. Sandy environments are common in many shallow settings $(0-$ $100 \mathrm{~m}$ ) in Lake Malawi today. We infer the presence of abundant terrigenous material to be indicative of shallow water environments; the sedimentary textures, sedimentary structures, and stratigraphic continuity of sand-rich intervals reinforce this interpretation. 


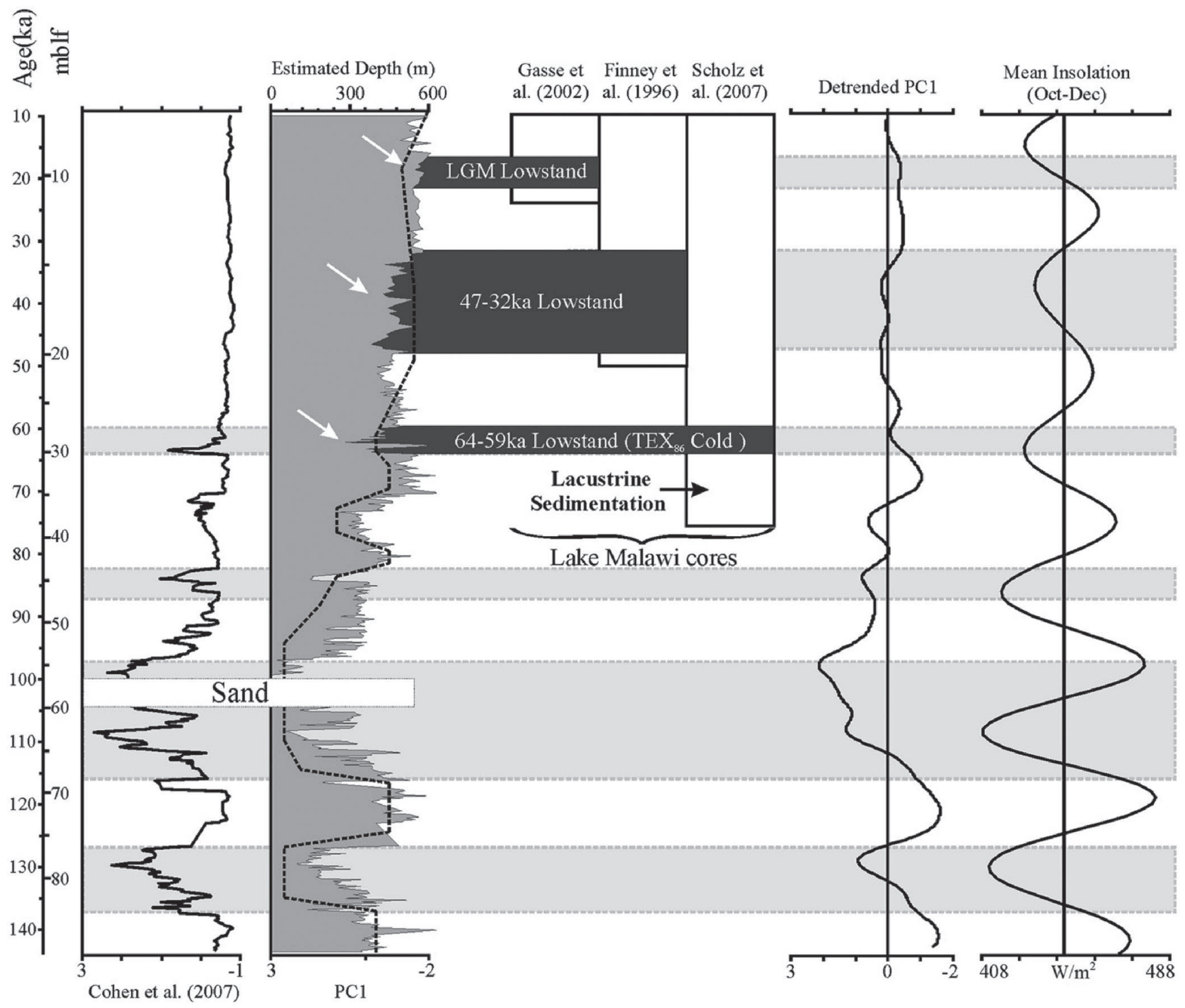

Figure 6. Lake-level reconstruction curves and associated supporting data. Reconstruction of Cohen et al. (2007), left, based upon wet-sieved variables only. Lake-level reconstruction based upon the principle component analysis from this study (PC1) overlain by the estimated depth curve (dashed line) of Lyons et al. (2011); depth estimates are based upon shoreline markers identified from seismic surveys of the lake basin. Arrows highlight significant lowstands observed in other late Pleistocene cores from Lake Malawi. Singular spectrum analysis-smoothed, linear-detrended PC1 curve displays a simplified pattern of lake fluctuations compared with $10^{\circ} \mathrm{S}$ summer insolation (right). Late Pleistocene lowstands (shaded) show a high level of correspondence with insolation minima.

\subsection{Multivariate analyses}

The first and second principal components (PC1 and PC2) cumulatively account for $\sim 29 \%$ of the variation in the dataset. We interpret PC1 as essentially a water-depth gradient; shallowwater indicators, including ostracodes, saline and alkaline species, terrigenous grains, carbonate coatings, and meroplankton common to the modern southern basin of Lake Malawi, show a strong positive correlation to this axis (Figure 5). Conversely, several deep-water indicators, including vivianite, chaoborids, freshwater euplankton and meroplankton common to the modern deep basins of Lake Malawi all show a strongly negative correlation to PC1. While this relationship seems relatively robust, there are a few diatom groups, such as tychoplankton and periphyton, which unexpectedly correlate to deep-water indicators.

The variance along PC2 appears related to diatom diversity. Groups that include species that tend to dominate the assemblage when they are present, such as saline euplankton and large granulatoid meroplankton are negatively correlated to PC2 (Figure 5), whereas groups associated with higher diversity, such as tychoplankton, periphyton, littoral plankton, and the A. ambigua group, are positively correlated to PC2.

\subsection{Paleohydrographic interpretation}

\subsubsection{4-136 ka (Diatom Zones M1 and M2)}

Fossil diatom assemblages from the base of Core $1 \mathrm{C}$ are strikingly different than those observed in the modern central basin. The dominant meroplankton belong to the Aulacoseira granulata v. valida group, suggesting that the lake was generally shallower and may have experienced more intense mixing than the modern central basin (Kilham and Kilham, 1975; Kilham et al., 1986; Kilham, 1990). Other plankton are a minor component of the assemblages; these are primarily represented by small euplanktic Stephanodiscus species, littoral plankton (e.g., Discostella stelligera), and small colonial tychoplankton. This diatom assemblage suggests an environment similar to 
the intermediate to deeper waters of the southern basin of the modern lake. Indeed, this section of Core 1C correlates to the top of Sequence III, as identified by Lyons et al. (2011), which is characterized by organic-rich sediments with an estimated water level $\sim 200 \mathrm{~m}$ below the modern lake (Figure 6). The absence of ostracode fossils and the presence of abundant chaoborid remains throughout most of this section indicate that the lake floor at the coring site was anoxic, which suggests water deeper than $\sim 250 \mathrm{~m}$. After $138 \mathrm{ka}$, rapidly-declining lake levels are inferred from the presence of ostracodes and increased abundance of terrigenous grains and carbonate coatings in the wet-sieved residue.

\subsubsection{6-122 ka (Diatom Zone M3)}

We interpret this zone as a phase of highly variable lake level. The fossil diatom assemblage is more diverse, has a greater percentage of euplanktic species, and is marked by numerous shifts in the dominant species. Residue from the wet sieve data also shows marked changes in the abundance of ostracodes, chaoborids, and carbonate coatings.

From 136 to $133 \mathrm{ka}, 20-40 \%$ of the diatom assemblage is characterized by a combination of Cyclostephanos malawiensis and $\mathrm{Cy}$ clotella aff. quillensis, with C. malawiensis often dominating and Aulacoseira granulata v. valida dominating the meroplankton. We interpret this period to represent continued shallowing from Diatom Zone M2. Increased abundance ostracodes and carbonatecoated grains coupled with the presence of saline/alkaline tolerant biota (Cyclotella aff. quillensis, Limnocythere), suggest at least periodic aerobic, ionically-concentrated environments at the coring site.

We infer a severe lowstand between 133 to $130 \mathrm{ka}$. Although it comprises less than $\sim 30 \%$ of the total assemblage, Cyclotella aff. quillensis replaces $C$. malawiensis as the dominant euplankton in this section of the core. This change is accompanied by a substantial increase in the total abundance of ostracodes; cypridopsine ostracodes are replaced by Limnocythere species, suggesting that the lake floor was above the oxycline at the core site and that salinity and/or alkalinity likely increased significantly throughout this period. This severe lowstand is equivalent to the base Sequence II, as defined by Lyons et al. (2011), which is characterized by organic-poor, carbonate-rich clays; the lowstand is estimated to be $\sim 500 \mathrm{~m}$ below the modern lake level based upon erosional packages of deltaic sediments identified from the seismic stratigraphy (Figure 6).

We interpret the period from 130 to $127 \mathrm{ka}$ as a lake refilling phase, indicated by the substantial increase in $C$. aff. quillensis accompanied by a decrease in meroplankton, suggesting a decrease in mixing depth. Ostracode abundance remains high, but Limnocythere are replaced by juvenile-dominated cypridopsine ostracode assemblages suggesting a deeper, dysaerobic environment at the coring site. These changes are supported by a reduction in terrigenous and carbonate-coated grains throughout this section.

Between 127 and $122 \mathrm{ka}$, the diatom assemblages change substantially; the meroplankton shifts from A. granulata v. valida to $A$. argus and $A$. nyassensis, and $C$. aff. quillensis is replaced by large-diameter stephanodiscoid euplankton. The new dominant diatom forms are all similar to those reported from the modern deep basins and suggest a decrease in salinity and a substantial increase in lake level. These changes in the diatom record are supported by the absence of ostracodes from the wet sieve residue and a sedimentological change in the core to organic-rich silts (Lyons et al., 2011). It is unclear exactly how deep the lake may have become during this period, but the absence of ostracodes suggests that the environment at the core site was deeper than the oxycline.

\subsubsection{2-116 ka (Diatom Zone M4)}

Marked changes in the euplankton and meroplankton occur at the base of this section; tropical granulatoid meroplankton are replaced by A. granulata v. muzzanensis with minor abundances of other diminutive, shallow-water forms. The response in the euplankton is less clear with multiple peaks in intermediate-sized stephanodiscoid and littoral plankton. Lake levels probably reached an early maximum at $\sim 119$ ka when vivianite crystals occur in the wet sieved residue. However, increases in the percentage of littoral plankton, periphyton, and tychoplankton suggest fluctuating lake levels and the occurrence of ostracodes, and terrigenous and carbonate-coated grains at the top of the zone, signal at least a temporary, but substantial, drop in lake level.

\subsubsection{6-86 ka (Diatom Zone M5)}

Diatom Zone M5 has been divided into 3 subzones (A-C), based primarily on transitions in the euplankton (Figure 3). The fossil meroplankton throughout Diatom Zone M5 is dominated by diverse assemblages of shallow-water Aulacoseira species, including A. ambigua and numerous varieties of A. granulata.

The euplanktic species in Diatom Zone M5A (116-109 ka) exhibit a distinct trend from peaks of large, deeper-water stephanodiscoid species at the base to a gradual increase in littoral plankton at the top of the subzone. This change is coupled with a gradual increase in the percent abundance of $A$. ambigua from the base of M5A to the top. Based on the high percentages of meroplankton commonly found in the shallow southern basin of the modern lake, we interpret this as a shallowing sequence. This interpretation is supported by low, spiky occurrences of ostracodes at the base of this subzone and a gradual increase in ostracode concentrations toward the top of the subzone. Elevated salinity is suggested by persistent low abundances of Cyclotella aff. quillensis, dominance of Limnocythere, and the concomitant increase in carbonate-coated grains and decrease in concentration of chaoborid fragments. Lyons et al. (2011) estimate another lowstand of $\sim 500$ meters below the modern lake level during this period based upon erosional packages of deltaic sediments identified from the seismic stratigraphy. A lowstand is also suggested by the core sedimentology, which returns to carbonate-rich clays with low organic matter (Scholz et al., 2011).

Diatom Zone M5B (109-92 ka) is defined by a dominance of shallow-water Aulacoseira species. Other plankton are a very minor component of the assemblages, and include shallow littoral Cyclotella species and C. aff. quillensis. We interpret this zone as an extremely low-lake phase that often mixed completely. The wet-sieved residue data support this interpretation: ostracodes are consistently abundant throughout most of this period, suggesting complete ventilation, Limnocythere dominate the ostracode assemblages, chaoborids are present in low concentrations, carbonate-coated grains are abundant, and terrigenous grains are higher than any other section of the core. The sedimentology of the core in this subzone is organic-poor, carbonate-rich clays with both nodular carbonate and gleyed, probable paleosols (Cohen et al., 2007) at the base of the subzone and a thick sand layer in the middle of the zone (105-100 ka), suggesting persistently low lake levels.

After $93 \mathrm{ka}$, the assemblage features an increasing percentage of $C$. aff. quillensis, while the Aulacoseira species composition remains relatively unchanged. We interpret this pattern, which continues through subsection M5C (92-86 ka) as another lake refilling phase. This interpretation is supported by a small increase in relative proportion of deeper-water Aulacoseira species near the top of the zone and a gradual loss of juvenile ostracodes, increased concentrations of chaoborids, and absence of carbonate-coated and terrigenous grains in the wet-sieved residue. The abundance of juvenile assemblages of cypridopsine os- 
tracodes at the top of this subzone (86 ka) suggests the seasonal oxycline was probably near the lake floor at the coring site.

\subsubsection{6-70 ka (Diatom Zone M6)}

Diatom assemblages in this zone are similar to those of Diatom Zone M3. The diverse, shallow-water Aulacoseira assemblage of zone $\mathrm{M} 5 \mathrm{C}$ is replaced by species of the A. granulata $\mathrm{v}$. valida group, the dominant euplankton (Stephanodiscus cf. medius) is present in higher abundances, and diversity is relatively low. We interpret this zone as a period of substantial lake-level fluctuation, on average deeper than M5C. Greater depths and enhanced stratification are suggested by a brief interval of vivianite $(\sim 81 \mathrm{ka})$ that correlates to a peak in A. nyassensis abundance. Minimum lake levels for this period are inferred from two intervals (centered at $\sim 85 \mathrm{ka}$ and $\sim 75 \mathrm{ka}$ ) of high ostracode abundance in the wet-sieved residue, which match maximum meroplankton dominance and the appearance of background levels of Thalassiosira sp. and Cyclotella aff. quillensis, suggesting slightly elevated salinity or alkalinity. Minimum lake depths within this section are probably $\sim 250 \mathrm{~m}$ at this site $(\sim 350 \mathrm{~m}$ below the modern lake level) placing the oxycline near or at the lake floor at the coring site. Total organic carbon and core sedimentology (Lyons et al., 2011) show a broadly similar pattern.

\subsubsection{0-55 ka (Diatom Zones M7 and M8)}

Diatom Zone M7 resembles the diatom communities of the modern central basin more closely than any of the previous zones. It is marked by an abrupt increase in species belonging to the Aulacoseira nyassensis group, elevated abundances of planktic Nitzschia species, and relatively low species diversity. Although the fossil diatom assemblages suggest a hydrography similar to present-day, the dominant euplanktic species in this period are substantially different, suggesting that the nutrient/water chemistry may not have been similar. Although the average depth of the lake was almost certainly fairly deep, lake levels probably continued to fluctuate substantially throughout this period. The wet-sieved residue data support the inference of generally higher lake levels; vivianite has several peaks throughout this interval, chaoborid concentrations increase, and, apart from a period between 64-62 ka, ostracodes are nearly absent from the sediments. This ostracode-rich interval probably represents a relatively brief, but substantial drop in the lake level as the coring site must have been oxygenated at least seasonally during this period. This brief lowstand is marked in the diatom record by peaks in Thalassiosira sp. and shallow-water Aulacoseira species. Evidence from the seismic data has constrained this lowstand as $\sim 200 \mathrm{~m}$ below the modern lake level (Scholz et al., 2007).

\subsubsection{5-42 ka (Diatom Zone M9)}

Aulacoseira agassizii v. malayensis replaces $A$. nyassensis as the dominant meroplankton throughout this period; this species is found more commonly in the modern southern basin and it is a very large-diameter form, capable of tolerating elevated alkalinity. Species of the Aulacoseira granulata v. valida group are also common and there are several intervals where Cyclotella ocellata is relatively abundant. We interpret this zone to represent (on average) shallower conditions than the antecedent diatom zones with lake depth at the coring site similar to that of the deeper water environments of the modern southern basin. Ostracodes are absent from the wet-sieved residue at this time, which suggests that the coring site was below the oxycline; vivianite formation was intermittent, but chaoborid concentrations were fairly high. The dominance of large-diameter Aulacoseira species typical of the southern basin may represent seasonal upwelling and enhanced mixing. At these depths, the southern basin would probably have been flooded, extending the surface area of the lake dramatically (Figure 1).

\subsubsection{2-31 ka (Diatom Zone M10)}

Hydrographically, this period was probably fairly similar to Diatom Zone M9, but the replacement of large-diameter $\mathrm{Au}$ lacoseira species by the smaller, shallow-water species A. ambigua suggests that lake levels may have decreased. The absence of vivianite during this period suggests that the bottom waters were ventilated, although not frequently enough to establish a well-developed ostracode community or significantly reduce the chaoborid concentrations. A small spike in ostracode abundance and maximum relative abundances of $A$. ambigua place the minimum depth at $\sim 250 \mathrm{~m}$ between 39-36 ka. After $36 \mathrm{ka}, A$. nyassensis and $A$. argus begin to gradually increase in abundance; around $33 \mathrm{ka}, A$. nyassensis replaces $A$. ambigua as the dominant meroplanktic species suggesting rising lake levels.

\subsubsection{1-16 ka (Diatom Zone M11)}

In this zone, Aulacoseira nyassensis and A. argus dominate the meroplankton. Increasingly stable water conditions are suggested by the concomitant increase of multiple stephanodiscoid species that are common in the modern lake, particularly the large-diameter species Stephanodiscus muelleri, which is a rare component of older fossil assemblages of Core 1C. We interpret these transitions in the fossil diatom assemblages to represent a steady increase in lake levels. Lake levels continued to rise throughout Diatom Zone M11, and by $23 \mathrm{ka}$, vivianite appears regularly in the wet-sieved residue. We interpret this zone as a transition to a very deep lake (probably greater than $400 \mathrm{~m}$ ) similar to the modern central basin; the water environment is deep and dilute with a highly stable water column. As the central basin deepened, the focus of upwelling probably shifted to the southern basin. Evidence of fluctuating lake levels near the top of the zone (from 23-17 ka), is provided by a small increase in periphytic Rhopalodia, changes in the relative abundances of $A$. argus and $A$. nyassensis, and variable vivianite abundances in the wet-sieved residue.

\subsubsection{6-10 ka (Diatom Zone M12)}

The final 6000 years of the core are dominated by Aulacoseira species associated with the deeper waters of the modern central basin, with relatively low diversity and limited abundances of stephanodiscoid species. We interpret this period as a deeper interval when lake levels may have fluctuated within $100 \mathrm{~m}$ of the modern lake level and water column stability declined significantly.

\section{Discussion}

\subsection{Lake-level reconstruction}

The inferred paleohydrography of much of the early part of this record includes conditions very different from those found in the modern lake system. Although we have not inferred specific depths for most of the reconstructed lake-level fluctuations, there is a strong correlation between the estimated depths of Lyons et al. (2011) and the general shape of the PC1 curve (Figure 6), which suggests that the variance of the sample scores in this dataset may be generally representative of absolute changes in lake depth.

In this dataset, the best indicators for calibrating specific lake depths are the concentrations of ostracodes and chaoborids in the sediment because their presence is constrained by the depth of the oxycline; in the modern lake, the depth of the oxycline has remained fairly constant (Eccles, 1974; Patterson and Kachinjika, 1995), but this does not preclude the possibility that substantially windier conditions and/or colder summers in the late Pleistocene may have resulted in periods of deeper ventilation. For example, between 62-64 ka, where the presence of ostracodes in the sediment indicates that the coring site was shal- 
lower than the oxycline, but results from the seismic survey have constrained the lake level to $\sim 200 \mathrm{~m}$ below the modern lake (Scholz et al., 2007); this suggests at least occasionally the oxycline may reached as deep as $400 \mathrm{~m}$ below the lake surface. Most other environmental indicators from the wet-sieved residue display a broadly consistent pattern with respect to inferred lake depths; for example, intervals interpreted to be maximum lowstands include abundant terrigenous and carbonate-coated grains together with indicators of higher salinity or alkalinity, such as ostracode assemblages dominated by Limnocythere.

Fossil diatom assemblages throughout the core also conform very well with the overall interpretation of the wet-sieved residue. Assemblages found in the open waters of the central basin today are associated with deep-water indicators and are minor components during inferred shallow intervals. Similarly, diatom species which are only observed in the southern basin today are typically associated with shallow-water indicators and periods of substantially low lake levels are always marked by a dramatic shift in the diatom assemblage.

Estimates of past lake levels from Core 1C presented in Cohen et al. (2007) are similar to those presented here (Figure 6), but the principle component analysis in that study did not incorporate the diatom record. The addition of diatom variables to the principle component analysis has created a more robust interpretation by providing additional depth indicators. The PC1 sample scores for both datasets are relatively similar, but the sample scores for PC1 from this study show a much higher degree of variability after $70 \mathrm{ka}$. This is probably a result of lower sensitivity to intermediate depths in the wet-sieved dataset, which has numerous indicators of shallow, very shallow, and very deep lake settings, but no indicators which represent intermediate depths. For example, most of the diatom zones inferred to represent environments similar to the deeper parts of the southern basin (i.e., lake depths ranging from 250 to $350 \mathrm{~m}$ ) are interpreted as very deepwater environments by Cohen et al. (2007).

Interestingly, the standard interpretation of shifts in tychoplankton and periphyton (i.e., increased relative abundances suggest shallower conditions) is often not congruent with our interpretation of past lake levels. For example, while both groups are abundant in some diatom zones interpreted to be shallow, they are present in relatively low abundances throughout Zone M5B. Zone M5B is unambiguously interpreted as a prolonged lowstand, based on multiple lines of evidence, including definitive ancient shoreline markers. Also, when deeper lake environments are indicated by other lines of evidence, tychoplankton and periphyton often have relatively high values (e.g. M7, M10, and M11). Given the weight of evidence against these zones representing shallow-water environments, alternative interpretations are required to explain the anomalous values. A substantial change in diatom flux rates across zones might produce a similar pattern, but our estimates of diatom productivity (valves/gm, unpublished data) do not support this explanation. A more probable explanation is that flooding of the southern basin and increases in nepheloid flows from river flooding results in a greater contribution of nearshore silt to the central basin during deeper lake settings. During prolonged lowstands, the basin configuration, or perhaps greater turbidity, may have resulted in a proportional loss of benthic habitat area near the coring site.

The Core 1C lake-level reconstruction shows a correspondence between lowstands and October-November insolation minima at $10^{\circ} \mathrm{S}$ (Figure 6). An exception to this pattern is the lowstand at 78-74 ka, which corresponds to an insolation maximum. Today, October marks the transition from the winter dry season to the summer wet season, which is associated with the southward migration of the ITCZ. Orbitally-forced variation in insolation is thought to have influenced the position of the summer season ITCZ in the past (Koutavas and Lynch-Stieglitz, 2005).

Variability in lake level (and by extension climate) is greatest prior to $70 \mathrm{ka}$, when the high eccentricity of the earth's orbit induced strong precession-forced variability in insolation. This is best illustrated by the detrended and smoothed PC1 curve in Figure 6. Reduced orbital-scale variability in lake level after $70 \mathrm{ka}$ is consistent with attenuated insolation variability; however, this does not explain the overall shift to higher lake levels and a more humid climate after $70 \mathrm{ka}$. Scholz et al. (2007) argued that the shift to a more humid climate may be associated with a shift from precessional to high-latitude forcing of tropical climate. Reduced variability in the lake level reconstruction after 70 ka may also be explained by the lower sensitivity of the depth-indicators when the lake levels are high. However, the lack of seismic indicators of major lake level fluctuations during this period suggests that lake levels were relatively stable.

\subsection{Supporting evidence}

Regional differences between the three Malawi lake basins, differences in the length and temporal resolution of records, and the absence of Holocene sediments in our record, make it difficult to directly substantiate our reconstructed lake levels against most other records from Lake Malawi. However, parts of Core $1 \mathrm{C}$ overlap with the $\sim 75 \mathrm{kyr}$ record from the northern basin presented by Scholz et al. (2007) and Brown et al. (2007), the 47+ kyr sediment archives reported by Finney et al. (1996), and the 24 kyr record presented by Gasse et al. (2002).

Seismic profiles and sediment stratigraphy of Core Mal05-2A (Figure 1; plotted as a filled circle) indicate that lake sedimentation in the northern basin began $\sim 75 \mathrm{ka}$ (Scholz et al., 2007); by $\sim 70 \mathrm{ka}$, the northern basin was accumulating well-laminated silty muds. The timing of this rise in lake level conforms very closely to the dramatic shift to deeper-water diatom assemblages in the central basin (Figures 2 \& 3; Diatom Zones M6 and M7). Brown et al. (2007) also discussed two prominent carbonate horizons in Core Mal05-2A, dated at $\sim 75 \mathrm{ka}$ and $\sim 62 \mathrm{ka}$. The former carbonate horizon was attributed to the initiation of lacustrine sedimentation in the northern basin and the latter to a substantial lowstand. These features are well-represented in our lake-level reconstruction. The inferred lowstand at $\sim 62 \mathrm{ka}$ closely matches a very brief period, marked in our record by a peak in Thalassiosira sp. (representing elevated salinity/alkalinity) and a sudden drop in Aulacoseira nyassensis, which represents the lowest inferred lake levels in the last $\sim 70 \mathrm{ka}$ (Figure 6). $\mathrm{TEX}_{86}$ data from Core Mal05-2A also mark this horizon as a period of substantially colder $\left(4^{\circ} \mathrm{C}\right)$ water temperatures (Woltering et al., 2011).

Finney et al. (1996) discussed three cores from the central basin of Lake Malawi recovered from $\sim 300 \mathrm{~m}$ of water (Figure 1; plotted as open circles). The cores were paired with a short seismic profile that extended nearly to the Core $1 \mathrm{C}$ site. Each of these cores featured a coincident increase in grain size and periphytic diatoms (Rhopalodia spp.), along with the presence of carbonates in the sediment, which was interpreted as a lowstand. Although the chronology of the Finney et al. (1996) cores was poorly constrained, evidence from the core, including possible erosional scouring, and seismic reflectors suggested that lake levels between 40 and $28 \mathrm{ka}$ were $\sim 200$ to $300 \mathrm{~m}$ below the modern lake level. As noted above, the lake level reconstruction of Cohen et al. (2007) gives no indication of a drop in lake level during this period (Figure 6); however, the reconstruction of lake level presented here suggests a significant drop in lake level between 47 to $30 \mathrm{ka}$, marked by the appearance of A. ambigua and littoral plankton, the disappearance of vivianite crystals, and a small, brief increase in the concentration of ostracodes in the sediment. This event is one of the few instances where PC1 markedly deviates from the interpretation of Lyons et al. (2011), as no accompanying shoreline markers have been found that substantiate this as a lowstand. A potential explanation for this discrepancy is that this interval may instead represent a period of significantly deeper mixing, resulting in a substantial change to nutrient cycling and the depth of the oxycline. 
Based upon a diatom record recovered from the northern basin of Lake Malawi, Gasse et al. (2002) inferred a $~ 100$ m drop in lake level during the Last Glacial Maximum (LGM, 23 to $19 \mathrm{ka}$ ). This drop in lake level is supported by erosional markers visible on seismic surveys of the Dwangwa delta sediments, which indicate lake levels $\sim 75 \mathrm{~m}$ below modern levels (Lyons et al, 2011). While we infer a relatively deep lake setting during the LGM compared to most of the late Pleistocene (Figure 6), fluctuating lake levels throughout this period are suggested by a modest increase in the abundance of tychoplankton and periphyton, and a decrease in the abundance of vivianite in the wet-sieved residue (Figure 4). We attribute the attenuated response in our record to differences in depth and distance from nearshore environments between the two coring sites; when lake levels are high, our depth indicators may not be sensitive to a 75-100 m drop in lake level.

\section{Summary}

Extreme lake-level fluctuations were a common occurrence in the late Pleistocene history of Lake Malawi. Changes in fossil diatom assemblages and wet-sieved residue data suggest that the lake was often significantly shallower than the modern lake, particularly prior to $\sim 70 \mathrm{ka}$. Our estimates of past lake levels suggest two periods of extreme aridity in the late Pleistocene occurring between 133-125 ka and 109-97 ka, during which the lake may have been less than $100 \mathrm{~m}$ deep at the coring site. Our reconstruction indicates that the early part of the record was also marked by substantial deeper-lake phases, which occurred from 144-136 ka and 122-116 ka. Water depths at the coring site during this period may not have reached the levels of the modern lake; however, deeper-water indicators are present and shoreline markers indicate depths of at least 300-400 m. Lake-level fluctuations during this period appear correlated to changes in insolation.

After $70 \mathrm{ka}$, our reconstruction indicates that the lake was deep, with fewer significant lowstands; a rapid transition from very shallow to deep water environments occurs from 97-70 ka, after which the lake became deep enough to begin generating continuous lake sediments in the northern basin. Between 62$64 \mathrm{ka}$ and 47-30 ka, two significant lowstands were inferred from substantial changes to the fossil diatom and ostracode assemblages. Evidence from other paleolimnological archives recovered from Lake Malawi support inferred lowstands during this period.

Acknowledgments - Funding for this project was provided by the U.S. National Science Foundation-Earth System History Program (EAR-0602350), the International Continental Scientific Drilling Program, and the Smithsonian Institution. Initial core processing and sampling was carried out at LacCore, the National Lake Core Repository at the University of Minnesota. Diatom sample preparation and analyses were conducted at the Fritz Lab at the University of Nebraska-Lincoln. We thank Chris Scholz and two reviewers for valuable suggestions that improved the manuscript. We also thank D.H. Jewson, S.C. Fritz, S. Spaulding, T.C. Johnson, W. Hobbs, and M. Julius for valuable discussions. Author contributions: A.S.C. designed research; J.R.S. \& A.S.C. performed research; J.R.S., K.S.W., and A.S.C. analyzed data.

\section{Appendix A.}

\section{Aulacoseira taxonomy}

Four of the six Aulacoseira species complexes (A. argus, A. nyassensis, $A$. agassizii, A. granulata) are broadly similar, and were designated by Müller (1904) as the Aulacoseira granulata group. Taxonomic identification of Aulacoseira belonging to this group, from fossil assemblages, is often hampered by the com- plex nature of morphological skeletal variation of specialized cells within individual colonial threads and similarities between individual valve forms between all four species complexes. Many of the varieties and subspecies (particularly of those belonging to the $A$. argus and $A$. nyassensis species complexes) were initially described from living material, where withinthread morphological variation is less problematic. In fossil assemblages, articulated threads are rare and disarticulated valves are often very difficult to separate with confidence under light microscope.

To facilitate paleolimnological interpretation, distinct forms were grouped, when possible, when these forms were determined to simply be specialized cells belonging to a taxon. When forms could be separated by pore size, pore shape, pore row density, or drastically differing valve dimensions, even in cases where forms may have been conspecific, these were counted and analyzed as independent forms to maintain their potential use for paleoenvironmental interpretation as ecomorphotypic variation.

Several of the A. granulata forms identified appear similar to the "transitional forms" described, informally, by Stager (1988) as the "granulata-agassizii group," observed from fossil assemblages in Lakes Cheshi, which appears related to A. granulata v. valida fo. robusta identified from Plio-Plistocene lakes in Ethiopia (Gasse, 1980), particularly the form described as "ancient form."

In this study, A. agassizii v. malayensis was distinguished from the "transitional forms" of A. granulata; strict attention was directed toward the alternating sequences of linking spines and the fine, rectangular pores, and the description of A. agassizii v. malayensis as being composed entirely of separation valves.

The Aulacoseira nyassensis species complex from the central basin included 10 identified forms, distinguished primarily by mantle pore size, shape, and pore row density. Three of the taxa separated resemble forms designated as subspecies of "variety peregrina"; this variety has never been formally transferred from the genus Melosira, but from observations in this material, we believe it may not warrant designation as a distinct variety. The original description distinguishes "peregrina" from the nominate primarily by size $(<20 \mu \mathrm{m})$, but where the two were found together in our samples, no clear boundary separating the populations was apparent and it seems likely that it is simply a smaller population (attenuated form) of the nominate. Six morphotypes of the nominate variety (and its subspecies) were identified; these include forms identical to those labeled types A-C described in Gasse et al. (2002) from late Pleistocene sediments of the northern basin of Lake Malawi.

Taxonomically, it is difficult to distinguish from the coarsepored morphotypes of $A$. nyassensis from A. argus, with which it is often found occurring together with in the fossil assemblages of this study. Although it was initially described from samples recovered from the deep water of Lake Malawi, A. argus has rarely been reported in abundance in modern studies; this may be partly due to its morphological similarity to the more widely-reported A. nyassensis. Along with the nominate form, a series of attenuated forms were described by Müller (1904), but poorly illustrated. In our samples, valves with sulci similar to $A$. argus and roughly matching the description of the minor forms (finer pores, smaller valve diameters) were quite common; although particularly narrow forms also appear to match the description of A. goetzeana. Because of the highly variable nature in the morphology of these attenuated forms along with the vague description and poor illustrations, we have separated two minor forms, one considerably narrow, which we have tenuously grouped as $A$. argus (minor).

In Core $1 C$, two forms of $A$. ambigua were identified; the most common form is a medium-sized species with relatively coarse pores, closely related to the specimens depicted as "status 3 " in Gasse (1980). The other form observed was a narrow, thin-walled variety with very fine pores, designated "status 1" by Gasse (1980), which typically co-occurred with the coarse-pored form. 


\section{Appendix B.}

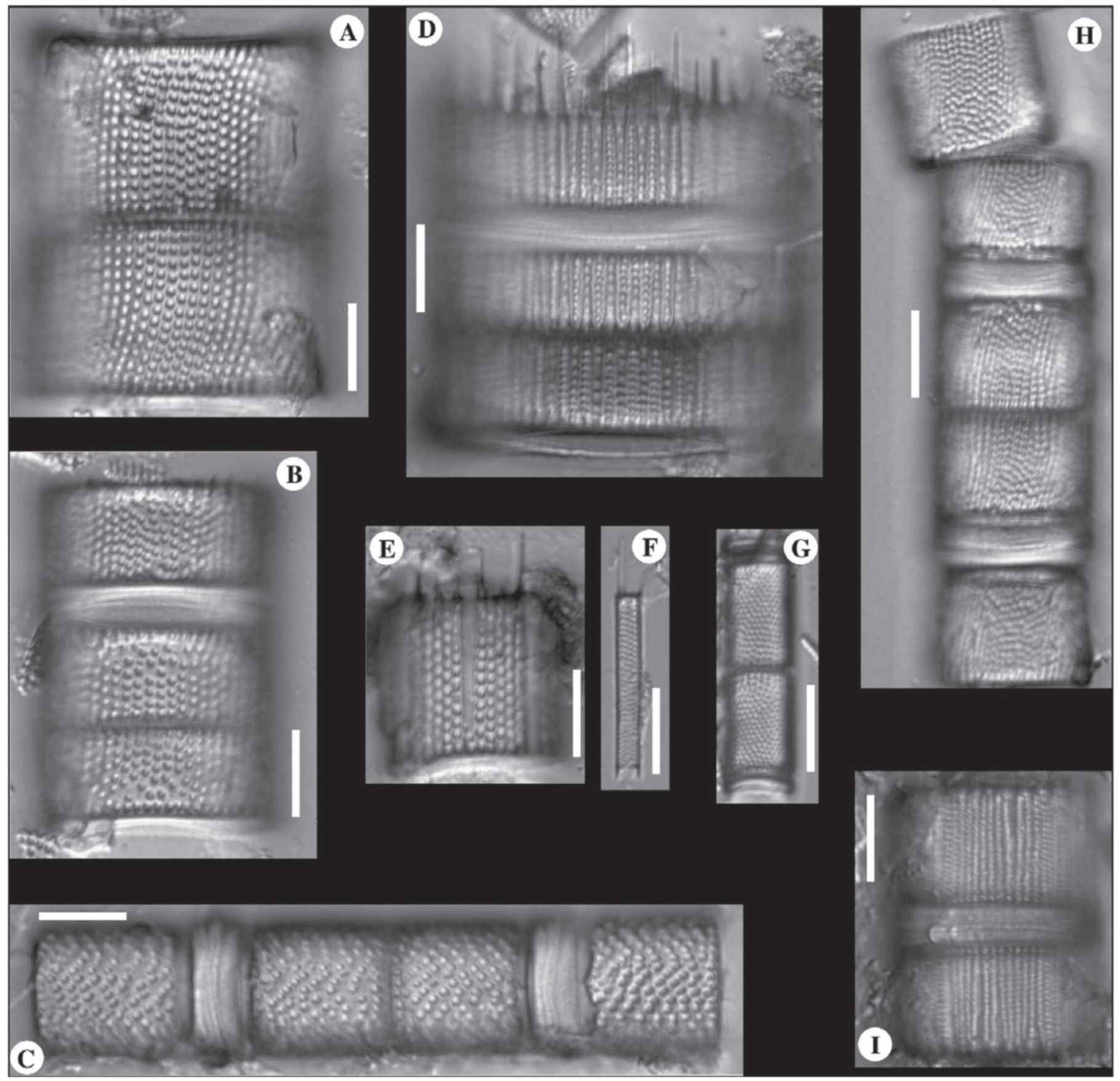

Appendix B - Plate 1. A) Aulacoseira nyassensis; B) Aulacoseira nyassensis; C) Aulacoseira argus; D) Aulacoseira agassizii v. malaysensis; E) Aulacoseira granulata fo. valida; F) Aulacoseira granulata v. angustissima; G) Aulacoseira ambigua; H) Aulacoseira ambigua (status 3); I) Aulacoseira granulata v. muzzanensis. All scale bars $10 \mu \mathrm{m}$.

\section{References}

Barker et al., 2003 • P. A. Barker, D. Williamson, F. Gasse and E. Gibert, Climatic and volcanic forcing revealed in a 50,000-year diatom record from Lake Massoko, Tanzania, Quaternary Res. 60 (2003), pp. 368-376.

Battarbee, 1986 - R. W. Battarbee, Diatom analysis. In: B. Berglund, ed., Handbook of Holocene palaeoecology and palaeohydrology, Wiley, New York, NY (1986), pp. 527-570.

Bennett, 1996 - K. D. Bennett, Determination of the number of zones in a biostratigraphical sequence, New Phytol. 132 (1996), pp. $155-170$.

Bennett, 2002 - K. D. Bennett, Documentation for psimpoll 4. 10 and pscomb 1.03 (2002) http:/ / www.kv.geo.uu.se/psimpoll.html

Bootsma et al., 2003 - H. A. Bootsma, R. E. Hecky, T. C. Johnson, H. J. Kling, and J. Mwita, Inputs, outputs, and internal cycling of silica in a large, tropical lake, J. Great Lakes Res. 29 (2003), pp. 121-138.

Brouwers, 1988 - E. M. Brouwers, Sediment transport detected from analysis of ostracod population structure: An example from the Alaska continental shelf. In: P. de Decker, J. P. Colin, and J. P. Peypouquet, eds., Ostracoda in the Earth Sciences, Elsevier, Amsterdam 


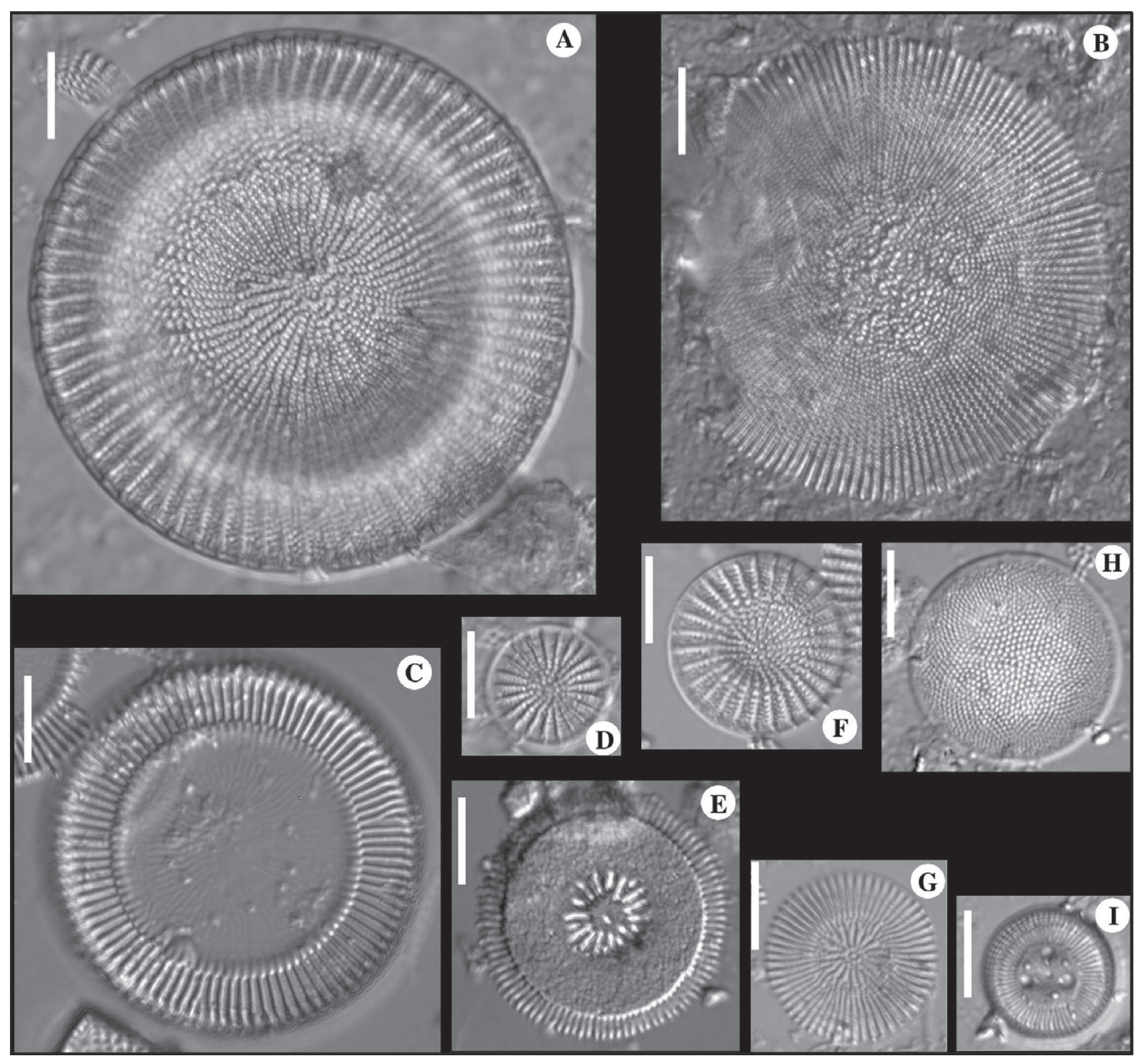

Appendix B - Plate 2. A) Stephanodiscus muelleri; B) Cyclostephanos damasii; C) Cyclotella cf. quillensis; D) Stephanodiscus nyassae; E) Discostella stelligera; F) Stephanodiscus aff. medius; G) Cyclostephanos malawiensis; H) Thalassiosira sp.; I) Cyclotella ocellata. All scale bars $10 \mu \mathrm{m}$.

(1988), pp. 231-244.

Brown et al., 2007 - E. T. Brown, T. C. Johnson, C. A. Scholz, A. S. Cohen, and J. W. King, Abrupt change in tropical African climate linked to the bipolar seesaw over the past 55,000 years, Geophys. Res. Lett. 34 (2007), p. L20702; doi: 10. 1029/2007GL031240.

Cocquyt et al., 1998 - C. Cocquyt, H. Lange-Bertalot, and J. P. Kociolek, Diatoms from the northern basin of Lake Tanganyika, J. Cramer, Berlin (1998), 275 pp.

Cohen, 2003 - A. S. Cohen, Paleolimnology: The history and evolution of lake systems, Oxford University Press, New York (2003) 500 pp.

Cohen et al., 2007 - A. S. Cohen, J. R. Stone, K. R. M. Beuning, L. E. Park, P. N. Reinthal, D. Dettman, C. A. Scholz, T. C. Johnson, J. W. King, M. R. Talbot, E. T. Brown, and S. J. Ivory, Ecological consequences of early Late Pleistocene megadroughts in tropical Africa, Proc. Natl. Acad. Sci. U.S.A. 104 (2007), pp. 16422-16427.

Eccles, 1974 - D. H. Eccles, An outline of the physical limnology of Lake Malawi (Lake Nyassa), Limnol. Oceanogr. 19 (1974), pp.
$730-742$

Finney et al., 1996 - B. P. Finney, C. A. Scholz, T. C. Johnson, and S. Trumbore, Late Quaternary lake-level changes of Lake Malawi. In: T. C. Johnson and E. O. Odada, eds., The limnology, climatology, and paleoclimatology of the East African lakes, Gordon and Breach Publishers, Amsterdam (1996), pp. 495-508.

Fritz, 1996 - S. C. Fritz, Paleolimnological records of climatic change in North America, Limnol. Oceanogr. 41 (1996), pp. 882-889.

Gasse, 1980 • F. Gasse, Les diatomées lacustres plio-pléistocènes du Gadeb, Revue Algologique, Paris (1980) 249 pp.

Gasse, 1986 - F. Gasse, East African diatoms: Taxonomy, ecological distribution. Bibl. Diatomol., Band 11, J. Cramer, Stuttgart (1986) 201 pp.

Gasse et al., 2002 • F. Gasse, P. Barker, and T. C. Johnson, A 24,000 yr diatom record from the northern basin of Lake Malawi. In: E. O. Odada and D. O. Olago, eds., The East African Great Lakes: Limnology, Paleolimnology and Biodiversity, Kluwer Academic Publishers, Netherlands (2002), pp. 393-414. 


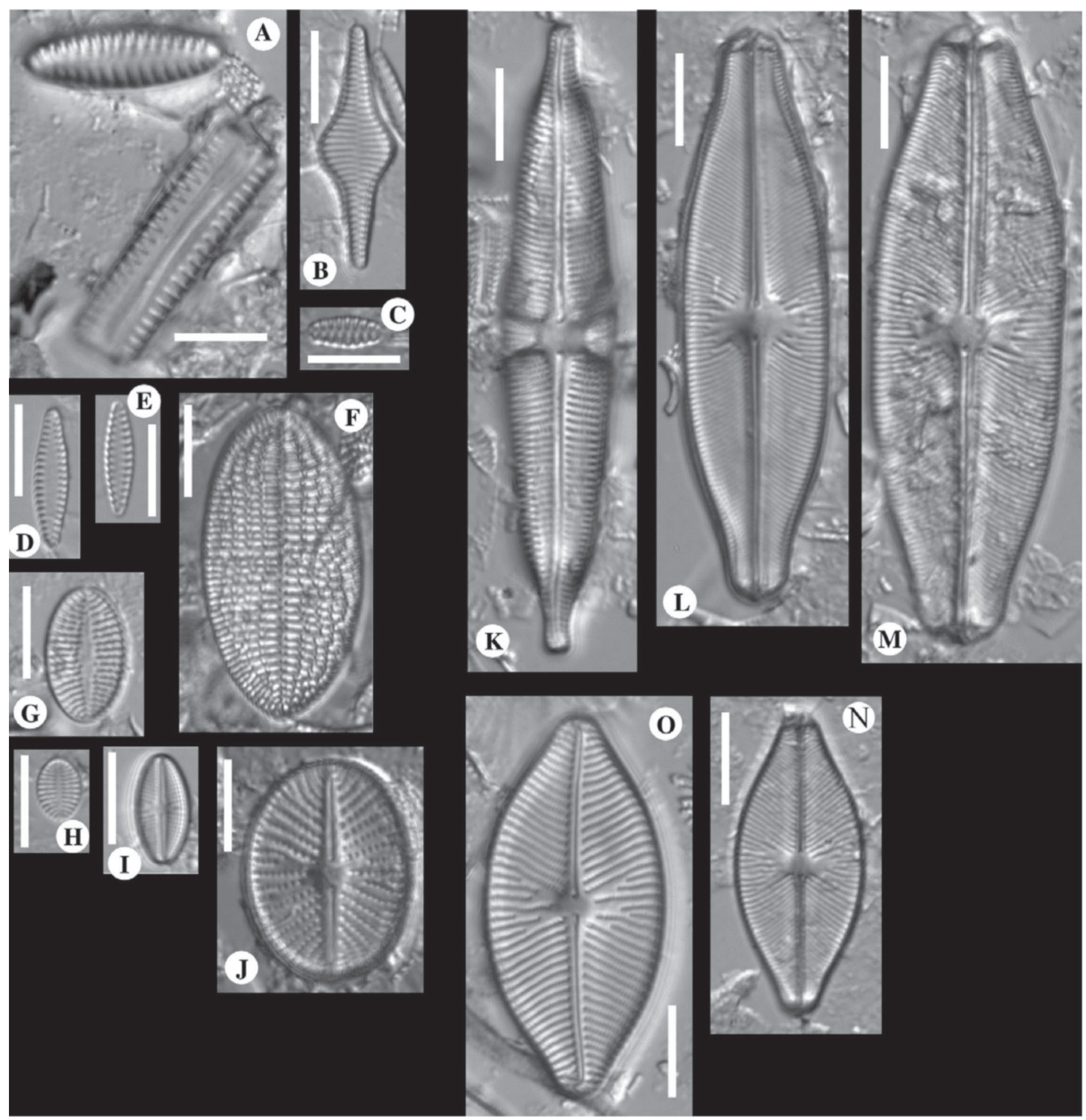

Appendix B - Plate 3. A) Staurosirella africana; B) Fragiliforma hungarica; C) Staurosirella pinnata; D) Pseudostaurosira brevistriata; E) Pseudostaurosira sp.; F) Cocconeis placentula v. euglypta; G) Cocconeis neodiminuta; H) Cocconeis neothumensis; I) Navicula seminuloides; J) Cavinula scutelloides; K) Capartagramma karstenii; L) Sellaphora nyassensis; M) Sellaphora mereschkowskii; N) Sellaphora malombensis; O) Placoneis gastrum. All scale bars 10 m.

Haberyan, 1990 - K. A. Haberyan, The misrepresentation of the planktonic diatom assemblage in traps and sediments: Southern Lake Malawi, Africa, J. Paleolimnol. 34 (1990), pp. 35-44.

Haberyan and Mhone, $1991 \bullet$ K. A. Haberyan and O. K. Mhone, Algal communities near Cape Maclear, southern Lake Malawi, Africa, Hydrobiologia 215 (1991), pp. 175-188.

Hecky and Kilham, 1973 - R. E. Hecky and P. Kilham, Diatoms in alkaline, saline lakes: Ecology and geochemical implications, Limnol. Oceanogr. 18 (1973), pp. 53-71.

Hecky and Kling, 1987 • R. E. Hecky and H. J. Kling, Phytoplankton ecology of the great lakes in the rift valleys of central Africa, Arch. Hydrobiol. Beihefte: Ergebnisse der Limnologie 25 (1987), pp. 197-228.

Hecky et al., 1996 - R. E. Hecky, H. A. Bootsma, R. M. Mugidde, and F. W. B. Bugenyi, Phosphorus pumps, nitrogen sinks, and silicon drains: Plumbing nutrients in the African Great Lakes. In: T. C. Johnson and E. O. Odada, eds., The limnology, climatology, and paleoclimatology of the East African lakes, Gordon and Breach Publishers, Amsterdam (1996), pp. 205-224.

Huisman and Sommeijer, 2002 • J. Huisman and B. Sommeijer, Maximal sustainable sinking velocity of phytoplankton, Mar. Ecol. Prog. 


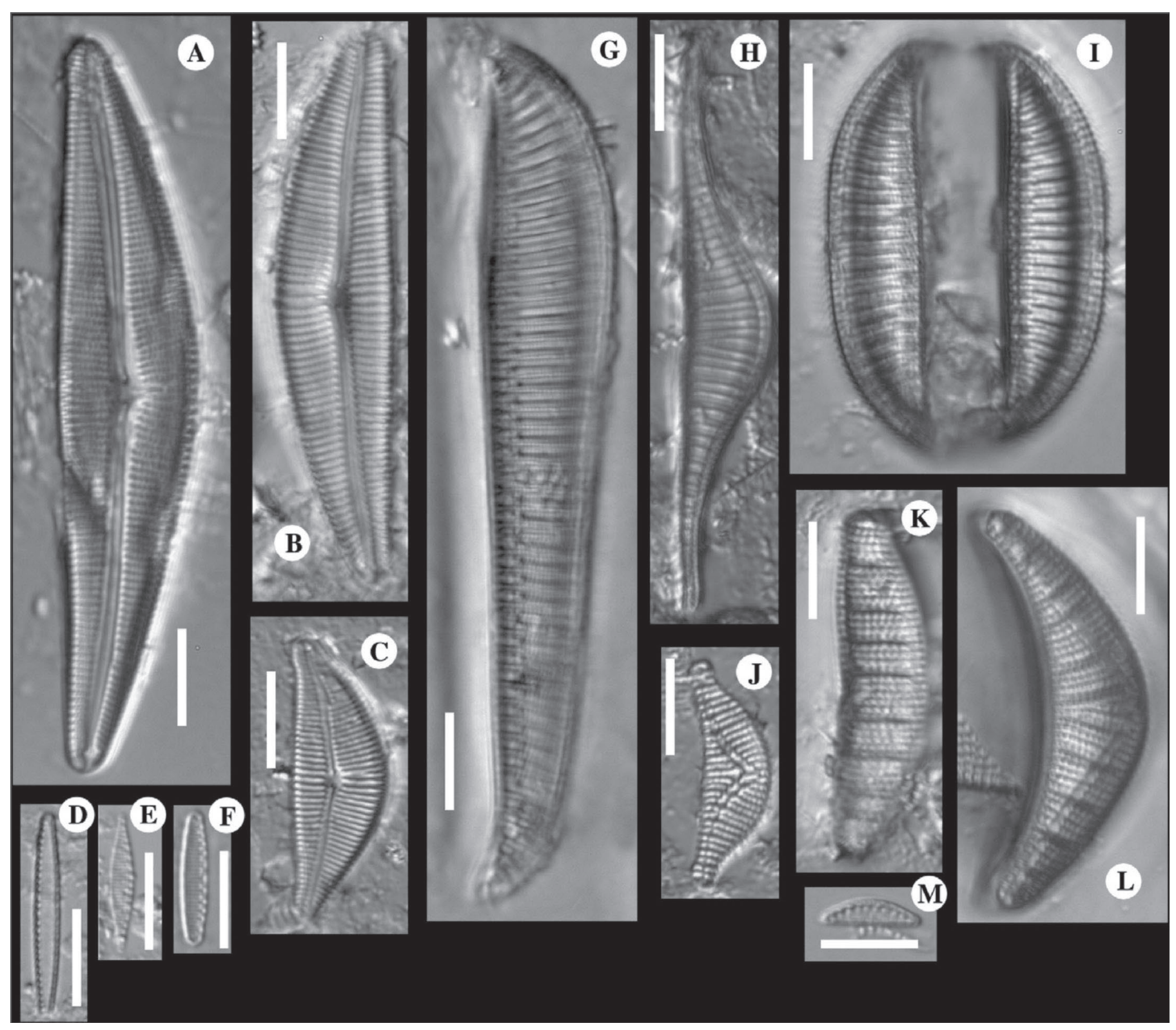

Appendix B - Plate 4. A) Gomphocymbella (Afrocymbella) pergracilis; B) Gomphocymbella (Afrocymbella) kociolekii; C) Gomphocymbella (Afrocymbella) muelleri; D) Nitzschia palea; E) Nitzschia fonticola; F) Nitzschia epiphyticoides; G) Rhopalodia hirundiformis; H) Rhopalodia cf. accuminata v. protracta; I) Rhopalodia cf. constricta; J) Epithemia sorex; K) Epithemia adnata; L) Epithemia cistula; M) Cymbellonitzschia minima. All scale bars $10 \mu \mathrm{m}$.

Ser. 244 (2002), pp. 39-48.

Jewson, 1992 - D. H. Jewson, Size reduction, reproductive strategy and the life cycle of a centric diatom, Philos. Trans. R. Soc. Lond., B, Biol. Sci. 336 (1992), pp. 191-213.

Johnson, 2002 - T. C. Johnson, Biogenic silica profiles in the sediments of large tropical lakes: Examples from East Africa. In: R. W. Renaut and G. M. Ashley, eds., Sedimentation in continental rifts, SEPM (Society for Sedimentary Geology, Tulsa, OK, USA (2002), pp. 247-255.

Johnson and McCave, 2008 • T. C. Johnson and I. N. McCave, Transport mechanism and paleoclimatic significance of terrigenous silt deposited in varved sediments of an African rift lake, Limnol. Oceanogr. 53 (2008), pp. 1622-1632.

Julius et al., in preparation - M. L. Julius, J. R. Stone, and K. Conroy, Cyclotella chinyanjaensis a new centric diatom diatom species from Pleistocene sediments with close relationship to the Cyclotella meneghiniana species complex, Phycol. Res. (in preparation).

Kilham, 1990 - P. Kilham, Ecology of Melosira species in the Great Lakes of Africa. In: M. M. Tilzer and C. Serruya, eds., Large lakes:
Ecological structure and function, Springer-Verlag, Berlin (1990), pp. 415-427.

Kilham and Kilham, 1975 • S. S. Kilham and P. Kilham, Melosira granulata (Ehr.) Ralfs: Morphology and ecology of a cosmopolitan freshwater diatom, Verh. Verein. Intern. Limnol. 19 (1975), pp. 2716-2721.

Kilham et al., 1986 • P. Kilham, S. S. Kilham, and R. E. Hecky, Hypothesized resource relationships among African planktonic diatoms, Limnol. Oceanogr. 31 (1986), pp. 1169-1181.

Klee and Casper, $1992 \cdot$ R. Klee and J. S. Casper, New centric diatoms (Thalassiosirales) of Lake Malawi (formerly Lake Nyassa; Malawi, East Africa), Arch. Protistenkd. 142 (1992), pp. 179-192.

Klee and Casper, $1996 \bullet$ R. Klee and J. S. Casper, Stephanodiscus nyassae Klee et Casper nov. spec., a new centric diatom, Arch. Protistenkd. 146 (1996), pp. 293-297.

Kociolek and Stoermer, 1990 - J. P. Kociolek and E. F. Stoermer, The diatom genus Gomphocymbella O. Müller: Taxonomy, ultrastructure and phylogenetic relationships, Nova Hedwigia Beiheft 106 (1990), pp. 71-91. 
Koutavas and Lynch-Stieglitz, 2005 - A. Koutavas and J. Lynch-Stieglitz, Variability of the marine ITCZ over the eastern Pacific during the past 30,000 years: Regional perspective and global context. In: R. Bradley and H. Diaz, eds., The Hadley Circulation: Present Past and Future, Springer (2005), pp. 347-369.

Krammer, 2003 - K. Krammer, Cymbopleura, Delicata, Navicymbella, Gomphocymbellopsis, Afrocymbella. In: Diatoms of Europe, vol. 4, H. Lange-Bertalot, ed., A. R. G. Gantner Verlag K. G., Ruggell (2003).

Krammer and Lange-Bertalot, 1986-1991 • K. Krammer and $\mathrm{H}$. Lange-Bertalot, Bacillariophyceae. In: H. Ettl, J. Gerloff, H. Heynig, and D. Mollenhauer, eds., Süsswasser flora von Mitteleuropa, Band 2/1-4, Gustav Fischer Verlag, Stuttgart (1986-1991).

Lyons et al., 2011 - R. P. Lyons, C. A. Scholz, M. R. Buoniconti, and M. R. Martin, Late Quaternary stratigraphic analysis of the Lake Malawi Rift, East Africa: An integration of drill-core and seismic-reflection data, Palaeogeogr. Palaeoclimatol. Palaeoecol. 303 (2011), pp. 20-37.

McQuoid and Hobson, 1996 • M. R. McQuoid and L. A. Hobson, Diatom resting stages, J. Phycol. 32 (1996), pp. 889-902.

Müller, 1903 - O. Müller, Bacillarien aus dem Nyassalande und einigen benachbarten Gebieten. Erste Folge., Bot. Jahrb. Syst. Pflanzengesch. Pflanzengeogr. 34 (1903), pp. 9-38.

Müller, 1904 • O. Müller, Bacillarien aus dem Nyassalande und einigen benachbarten Gebieten. Zweite Folge, Bot. Jahrb. Syst. Pflanzengesch. Pflanzengeogr. 34 (1904), pp. 256-301.

Müller, 1905 - O. Müller, Bacillarien aus dem Nyassalande und einigen benachbarten Gebieten. Dritte Folge, Bot. Jahrb. Syst. Pflanzengesch. Pflanzengeogr. 36 (1905), pp. 137-205.

Müller, 1910 • O. Müller, Bacillarien aus dem Nyassalande und einigen benachbarten Gebieten. Vierte Folge, Bot. Jahrb. Syst. Pflanzengesch. Pflanzengeogr. 45 (1910), pp. 69-122.

Nicholson, 1998 - S. E. Nicholson, Historical fluctuations of Lake Victoria and other lakes in the northwestern Rift Valley of East Africa. In: J. T. Lehman, ed., Environmental Change and Response in East African Lakes, Kluwer Academic Publishers, Netherlands (1998), pp. 7-35.

Owen and Crossley, 1992 - R. B. Owen and R. Crossley, Spatial and temporal distribution of diatoms in sediments of Lake Malawi, J. Paleolimnol. 7 (1992), pp. 55-71.

Owen et al., 1990 - R. B. Owen, R. Crossley, T. C. Johnson, D. Tweddle, I. Kornfield, S. Davison, D. H. Eccles, and D. E. Engstrom, Major low levels of Lake Malawi and their implications for speciation rates in cichlid fish, Proc. R. Soc. London Ser. B 240 (1990), pp. 519-533.

Paillard et al., 1996 - D. Paillard, L. Labeyrie, and P. Yiou, Macintosh program performs time-series analysis, EoS Trans, AGU 77 (1996), p. 379 .

Palacios-Fest et al., 2005 M. R. Palacios-Fest, S. R. Alin, A. S. Cohen, B. Tanner, and H. Heuser, Paleolimnological investigations of anthropogenic environmental change in Lake Tanganyika: IV. Lacustrine paleoecology, J. Paleolimnol. 34 (2005), pp. 51-71.

Park and Cohen, 2011 - L. E. Park and A. S. Cohen, Paleoecological response of ostracods to early-late pleistocene lake level changes in Lake Malawi, East Africa, Palaeogeogr. Palaeoclimatol. Palaeoecol. 303 (2011), pp. 71-80.

Park et al., 2003 - L. E. Park, A. S. Cohen, K. Martens, and R. Bralek, The impact of taphonomic processes on interpreting paleoecological changes in large lake ecosystems: Ostracodes in Lakes Tanganyika and Malawi, J. Paleolimnol. 30 (2003), pp. 127-138.

Patterson and Kachinjika, 1995 - G. Patterson and O. Kachinjika, Limnology and phytoplankton ecology. In: A. Menz, ed., The fishery potential and productivity of the pelagic zone of Lake Malawi/Niassa, Natural Resource Institute, Chatham, UK (1995), pp. 1-67.

Pilskaln, 2004 - C. H. Pilskaln, Seasonal and interannual particle export in an African Rift Valley lake: A 5-yr record from Lake Malawi, southern East Africa, Limnol. Oceanogr. 49 (2004), pp. 964-977.

Pilskaln and Johnson, 1991 - C. H. Pilskaln and T. C. Johnson, Seasonal signals in Lake Malawi sediments, Limnol. Oceanogr. 36 (1991), pp. 544-557.

Ruhland et al., 2008 - K. Ruhland, A. M. Patterson, and J. P. Smol, Hemispheric-scale patterns of climate-related shifts in planktonic diatoms from North American and European lakes, Glob. Change Biol. 14 (2008), pp. 1-15.

Ryves et al., 2003 - D. B. Ryves, D. H. Jewson, M. Sturm, R. W. Battarbee, R. J. Flower, A. W. Mackay, and N. G. Granin, Quantitative and qualitative relationships between planktonic diatom communities and diatom assemblages in sedimenting material and surface sediments in Lake Baikal, Siberia. Limnol. Oceanogr. 48 (2003), pp. 1643-1661.

Scholz et al., 2007 - C. A. Scholz, T. C. Johnson, A. S. Cohen, J. W. King, J. A. Peck, and J. T. Overpeck, East African megadroughts between 135 and 75 thousand years ago and bearing on early-modern human origins, Proc. Natl. Acad. Sci. U. S. A. 104 (2007), pp. 16416-16421.

Scholz et al., 2011 - C. A. Scholz, A. S. Cohen, T. C. Johnson, and J. W. King, Scientific Drilling in the Great Rift Valley: The 2005 Lake Malawi Scientific Drilling Project-An overview of the past 145,000 years of climate variability in Southern Hemisphere East Africa, Palaeogeogr. Palaeoclimatol. Palaeoecol. 303 (2011), pp. 3-19.

Sicko-Goad et al., 1986 • L. Sicko-Goad, E. F. Stoermer, and G. Fahnenstiel, Rejuvenation of Melosira granulata resting cells from the anoxic sediments of Douglas Lake, Michigan. I. Light microscopy and 14C uptake, J. Phycol. 22 (1986), pp. 22-28.

Spigel and Coulter, 1996 - R. H. Spigel and G. W. Coulter, Comparison of hydrology and physical limnology of the East African Great Lakes: Tanganyika, Malawi, Victoria, Kivu and Turkana (with reference to some North American Great Lakes). In: T. C. Johnson and E. O. Odada, eds., The limnology, climatology, and paleoclimatology of the East African lakes, Gordon and Breach Publishers, Amsterdam (1996), pp. 103-139.

Stager, 1988 - J. C. Stager, Environmental changes at Lake Chesni, Zambia since 40,000 years B.P., Quaternary Res. 29 (1988), pp. 54-65.

Stone and Fritz, $2004 \cdot$ J. R. Stone and S. C. Fritz, Three-dimensional modeling of lacustrine diatom habitat areas: Improving paleolimnological interpretation of planktic:benthic ratios, Limnol. Oceanogr. 49 (2004), pp. 1540-1548.

ter Braak and Šmilauer, 2002 - C. J. F. ter Braak and P. Šmilauer, Canoco Reference manual and CanoDraw for Windows User's Guide: Software for Canonical Community Ordination (version 4. 5), Microcomputer Power, Ithaca, NY, USA (2002).

Tilman and Kilham, 1976 - D. Tilman and P. Kilham, Sinking in freshwater phytoplankton: Some ecological implications of cell nutrient status and physical mixing processes, Limnol. Oceanogr. 21 (1976), pp. 409-417.

Tolotti et al., 2007 - M. Tolotti, F. Corradini, A. Boscaini, and D. Calliari, Weather-driven ecology of planktonic diatoms in Lake Tovel (Trentino, Italy), Hydrobiol. 578 (2007), pp. 147-156.

Torrance, 1972 - J. D. Torrance, Malawi, Rhodesia, and Zambia. In: J. F. Griffiths, ed., Climates of Africa. World Survey of Climatology, 10, Elsevier, Amsterdam (1972), pp. 409-455.

Tuchman et al., $1984 \cdot$ M. L. Tuchman, E. Theriot, and E. F. Stoermer, Effects of low level salinity concentrations on the growth of Cyclotella quillensis Kütz. (Bacillariophyta), Arch. Protistenkd. 128 (1984), pp. 319-326.

Vollmer et al., 2005 - M. K. Vollmer, H. A. Bootsma, R. E. Hecky, G. Patterson, J. D. Halfman, J. M. Edmond, D. H. Eccles, and R. F. Weiss, Deep-water warming trend in Lake Malawi, East Africa, Limnol. Oceanogr. 50 (2005), pp. 727-732.

Whatley, 1988 - R. C. Whatley, Population structure of ostracods: Some general principles for the recognition of palaeoenvironments. In: P. de Decker, J. P. Colin and J. P. Peypouquet, eds., Ostracoda in the Earth Sciences, Elsevier, Amsterdam (1988), pp. 245-256.

Winder and Hunter, 2008 - M. Winder and D. A. Hunter, Temporal organization of phytoplankton communities linked to physical forcing, Oecologia 156 (2008), pp. 179-192.

Winder et al., 2008 - M. Winder, J. E. Reuter, and S. G. Schladow, Lake warming favours small-sized planktonic diatom species, Proc. R. Soc. B (2008), pp. 1-9; doi: 10.1098/rspb.2008.1200.

Wolin and Duthie, 1999 - J. A. Wolin and H. C. Duthie, Diatoms as indicators of water level change in freshwater lakes. In: E. F. Stoermer and J. P. Smol, eds., The diatoms: Applications for the environmental and earth sciences, Cambridge University Press (1999), pp. 183-202.

Woltering et al., 2011 • M. Woltering, T. C. Johnson, J. P. Werne, S. Schouten, and J. S. Sinninghe Damsté, Late Pleistocene temperature history of Southeast Africa: A TEX 86 temperature record from Lake Malawi, Palaeogeogr. Palaeoclimatol. Palaeoecol. 303 (2011), pp. 93-102.

Wüest et al., 1996 • A. Wüest, G. Piepke, and J. D. Halfman, Combined effects of dissolved solids and temperature on the density stratification of Lake Malawi. In: T. C. Johnson and E. O. Odada, eds., The limnology, climatology, and paleoclimatology of the East African lakes, Gordon and Breach Publishers, Amsterdam (1996), pp. 183-204. 